\title{
Alsónyék-Bátaszék: \\ a new chapter in the research of Lengyel culture
}

\author{
Anett Osztás, István Zalai-Gaál and Eszter Bánffy \\ Institute of Archaeology, Research Centre for the Humanities, Hungarian Academy of Sciences, Budapest, HU \\ osztas.anett@btk.mta.hu \\ gaal.istvan@btk.mta.hu; banffy.eszter@btk.mta.hu
}

\begin{abstract}
There can be no doubt that one of the major archaeological discoveries made in Hungary during the past ten years was the prehistoric settlement at Alsónyék-Bátaszék. The area was intermittently occupied from the Early Neolithic to the end of the Late Neolithic and the onset of the Copper Age. The prehistoric settlement attained its greatest extent during the Late Neolithic Lengyel period, as shown by the 2359 burials and over 100 post-framed buildings uncovered at the site. This preliminary report describes previous research on the architecture of the Late Neolithic Lengyel culture in Hungary and the Lengyel settlement at Alsónyék and its architecture.
\end{abstract}

IZVLEČEK - Prazgodovinska naselbina pri kraju Alsónyék-Bátaszék je nedvomno eno izmed največjih odkritij na Madžarskem v zadnjih desetih letih. Območje je bilo s prekinitvami poseljeno od zgodnjega neolitika do konca poznega neolitika in začetka bakrene dobe. Prazgodovinska naselbina je doživela svoj največji razpon v pozno-neolitski kulturi Lengyel, kar dokazuje 2359 izkopanih pokopov in več kot 100 stavb, grajenih v tehniki sohaste gradnje. V tem preliminarnem poročilu opisujemo dosedanje raziskave arhitekture pozno-neolitske kulture Lengyel na Madžarskem in arhitekturo lengyelske naselbine pri kraju Alsónyék.

KEY WORDS - Late Neolithic; Lengyel culture; settlement structure; architecture; above-ground timber-framed buildings

\section{Introduction}

The Alsónyék-Bátaszék site lies in south-eastern Transdanubia, in the south-western part of the Tolna Sárköz region (Fig. 1). ${ }^{1}$ It is bounded by the Szekszárd Hills in the west and by the wide alluvial plains of the former Danube channels in the east. The site rises above the alluvial plain of the Danube. Its surroundings are dotted by island-like ridges lying at 92-94m a.s.l., higher than the average 86-87m a.s.l. of the area, as well as of the infilled river and stream channels. The bed of the Lajvér Stream extends across the middle of the excavated area (Pl. 1). The river regulations had completely changed the original geomorphological features of the area by the late $19^{\text {th }}$ century.
The site lies near the Danube, the main natural communications artery, and at the meeting point of two different regions, the Transdanubian Hills and the Great Hungarian Plain. On a larger scale, it lies in the contact zone between the Neolithic populations of the northern Balkans and Central Europe. This geographical location left its imprint on the archaeological record, which is reflected in clear signs of cultural influences from the south in the material of all Neolithic periods recorded at the site.

The site was investigated during the archaeological excavations preceding the construction of the M6 motorway between 2006 and 2009. In addition to

1 Abbreviated as Alsónyék in the following. 
the Institute of Archaeology of the Hungarian Academy of Sciences, several other institutions also participated in the excavations conducted at several locations independently of each other owing to the tight excavation schedule (Pl. 1). However, it soon became clear that the different locations were all part of a single, very extensive Neolithic site. The roughly 15000 features uncovered reflect the site's intensive occupation and the large, c. $250000 \mathrm{~m}^{2}$ area of the excavations. About $90 \%$ of the uncovered features could be assigned to the Neolithic: the Starčevo culture, the Central European Linearbandkeramik (LBK), the Sopot culture and Lengyel culture. The proportion of finds from other periods (Bronze Age, Iron Age, Roman Age) was considerably smaller. Several studies discussing the site and its finds have already been published, ranging from preliminary reports (Bánffy et al. 2010; Gallina et al. 2010; Gelencsér 2010; Majerik et al. 2010) to articles devoted to a particular aspect (Zalai-Gaál 2008; Zalai-Gaál, Osztás 2009a; 2009b; Zalai-Gaál et al. 2009; 2010; 2011a; 2011b; 2012).2

\section{The occupants of Alsónyék before the Lengyel culture}

\section{The Starčevo culture}

The first Neolithic inhabitants in the area were population groups of the Starčevo culture. In Hungary, the archaeological investigation of this culture began in the 1970s, when the culture's first sites were discovered. Since then, over 30 sites have been documented in Transdanubia, most of which lie in the Danube and Dráva valleys, the Sió-Sárvíz valley and in the north to south stream valleys (Kalicz et al. 2007a.25; Kalicz 2011.105-107; Abb. 1.1). In terms of its location, the Alsónyék site fits into the chain of already known sites. Our knowledge of Starčevo culture is based on small-scale excavations and salvage operations, and the findings of field surveys (Kalicz 2011.111). Some 500 features of the Starčevo settlement were uncovered in the south-eastern part of the excavated area at Alsónyék (Fig. 2). We must mention the roughly 100 ovens and thirty graves in which the deceased were buried in a contracted position. 3 The archaeological features have their best parallels in the Starčevo sites in Croatia, as far as the large, irregular pits, the oven types and

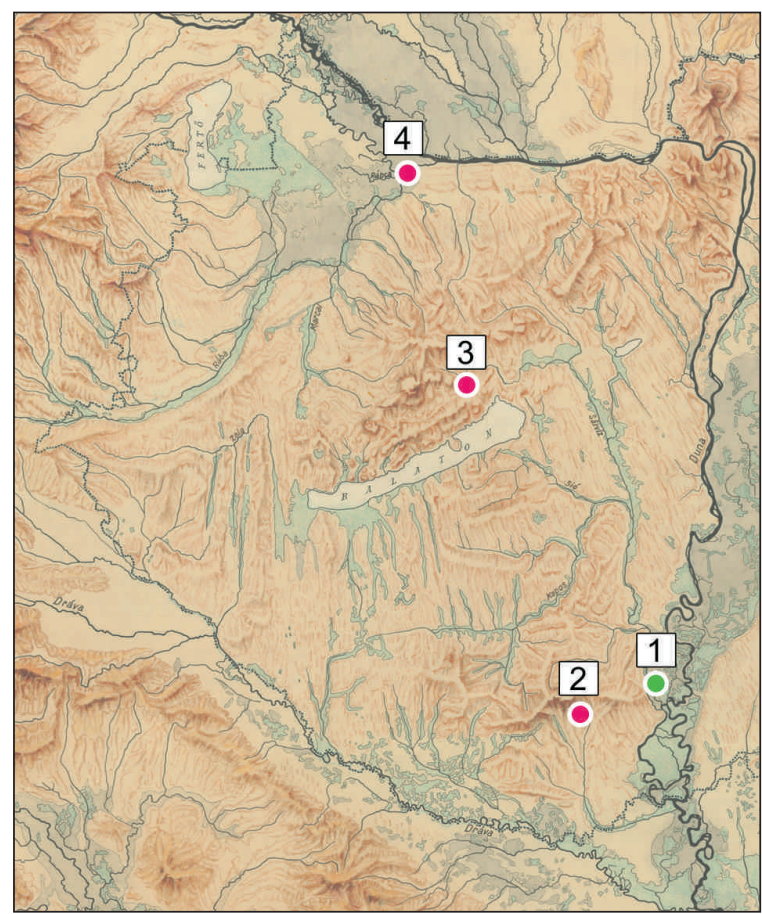

Fig. 1. Location of Alsónyék-Bátaszék and the main Hungarian sites of Lengyel culture with timber-framed houses. 1 Alsónyék-Bátaszék; 2 Zengóvárkony; 3 Veszprém-Jutasi út; 4 Gyốr-Szabadrétdomb.

the burials are concerned (Minichreiter 2007.Fig. 5, Figs. 15-16, Fig. 21a-b; Minichreiter, Botić 2010). Knowing that the northern fringes of the BalkanAegean Early Neolithic culture province lay in southern Transdanubia, it is hardly surprising that these sites are most closely allied to settlements in Croatia and the Srem, because all three regions were part of the same cultural complex (Kalicz et al. 2007a. 25 ). The typological traits and decoration of the ceramics indicate that one part of the Starčevo settlement at Alsónyék can be dated to the culture's late phase (Bánffy et al. 2010), although an earlier occupation can also be assumed, as some finds exhibit the traits of an earlier phase.

It is generally assumed that surface-level, timberframed buildings had existed already during the Starčevo period, because the presence of post houses has been documented on sites of the contemporaneous Körös culture (for a recent overview, $c p$. Raczky 2006). However, the number of Starčevo sites is well below the currently known Körös sites

2 The cleaning and conservation of the finds from certain excavation areas are still in progress. The assessment of a part of the finds is performed as part of a research project directed by Eszter Bánffy, supported by Grant K 81230 of the Hungarian Scientific Research Fund (OTKA).

3 The settlement features and the most important finds from the Early Neolithic settlement have been described in a preliminary report (Bánffy et al. 2010). This description is based on the excavation data of the intensively occupied Starčevo settlement in the south-eastern part of the excavated area. The exact number of ovens and burials has since been modified (Gallina et al. 2010). 


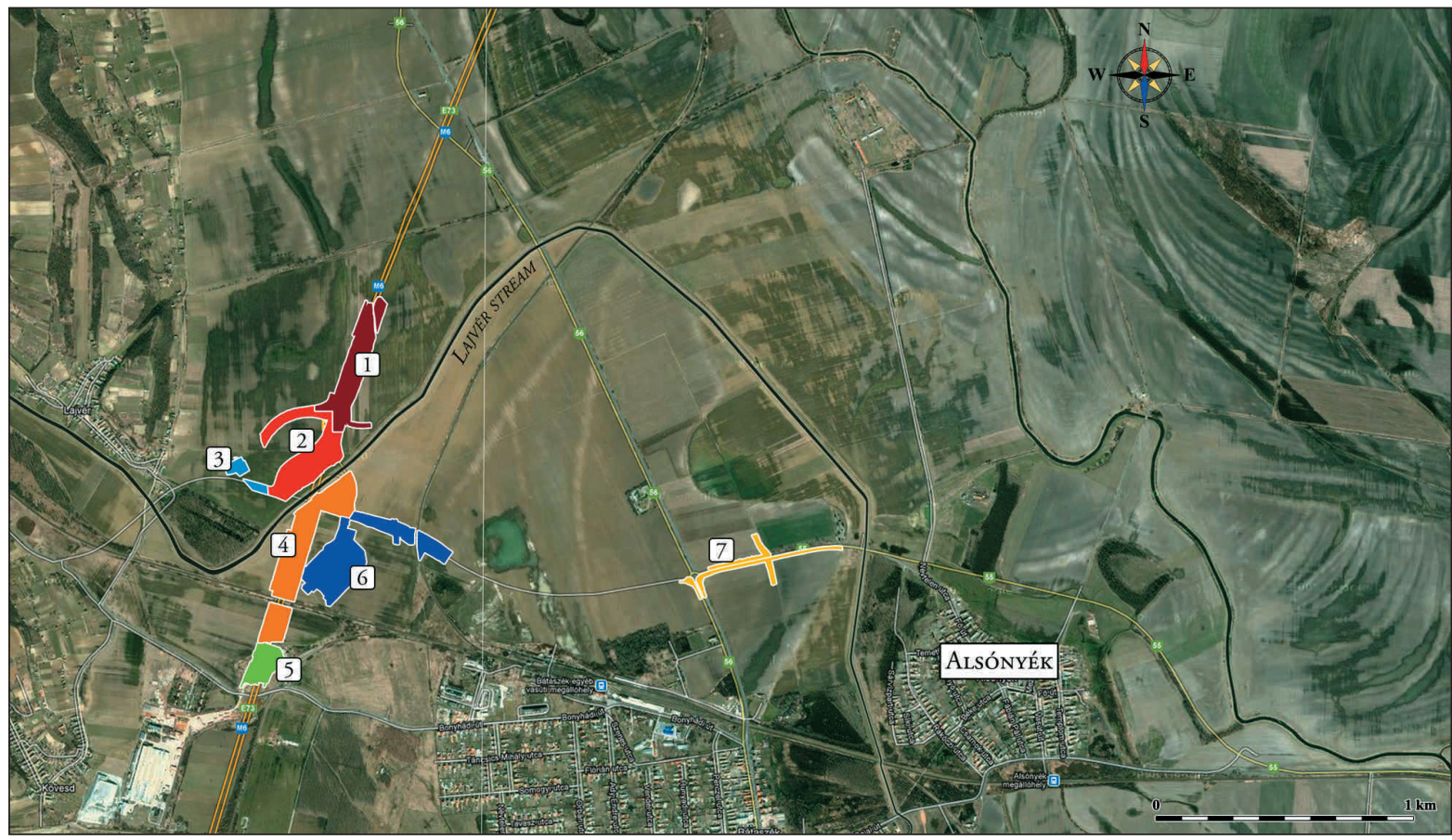

Pl. 1. Alsónyék-Bátaszék. Plan of the excavations. 1 Site M6 TO 10/B, Alsónyék-Kanizsa-dúló. Excavated by the Institute of Archaeology of the Hungarian Academy of Sciences and Archeosztráda Ltd. between 2006 and 2008, excavation conducted by Anett Osztás and István Zalai-Gaál. Excavated area: 42 076m²; 2 Site M6 TO 10/B, Alsónyék-Kanizsa-dúló. Excavated by Asatárs Ltd. in 2006-2007, excavation conducted by Zsolt Gallina. Excavated area: $47038 \mathrm{~m}^{2}$; 3 Site M6 TO 046, Lajvérpuszta. Excavated by the Field Service for Cultural Heritage in 2008-2009, excavation conducted by Vera Majerik. Excavated area: 6799m²; 4 Site M6 TO 11, Bátaszék-Malomrét-dúlö. Excavated by Ásatárs Ltd. in 2006-2007, excavation conducted by Péter Hornok and Zsolt Gallina. Excavated area: 67 095m²; 5 Site M6 TO 11, Magtár. Excavated by the Field Service for Cultural Heritage in 2008, excavation conducted by Vera Majerik. Excavated area: 16 253m²; 6 Site M6 T0 5603/1, Bátaszék-Mérnökségi Telep and Bátaszék-56-os út. Excavated by the Institute of Archaeology of the Hungarian Academy of Sciences and Archeosztráda Ltd. in 20082009, excavation conducted by Anett Osztás. Excavated area: $63488 \mathrm{~m}^{2}$; 7 Site M6 T0 5603/2, Alsónyék Hosszú dúló. Excavated by the Wosinsky Mór County Museum in 2008-2009, excavation conducted by János Ódor. Excavated area: $10210 m^{2}$.

(Bittner 2012a; 2012b; Dani 2012; Kustár 2012; Paluch 2012; Siklósi 2012). Not one single surfacelevel, timber-framed Starčevo house has yet been found in Hungary, and the Alsónyék site is no exception in this respect.

\section{The $\mathrm{LBK}$}

A major settlement of the Central European LBK was uncovered in the central area of the investigated area (Fig. 2). In addition to various pits and a few ditches, a substantial number of the long pits (Längsgrube) flanking the houses were also uncovered. The remains of some 20 houses were identified in all. However, indications of the timber framework of these buildings could only be observed in a few cases and thus these house plans are unsuited to a more detailed architectural analysis. None of the burials could be securely dated to the LBK period. Excavations conducted as part of the M6 salvage operations at another LBK settlement discovered at
Tolna-Mözs lying some $20 \mathrm{~km}$ north of Alsónyék brought to light the remains of 47 surface-level, postframed buildings (Marton, Oross 2012). The significance of these sites lies in that they represent the southernmost LBK settlements in Transdanubia. Disregarding the southern shores of Lake Balaton, none of the previously known sites in southern Transdanubia yielded the remains of above-ground, timberframed houses (Oross, Bánffy 2009.Fig. 9). The sites are also remarkable regarding their find material, which to some extent reflects the geographical location of these sites, as the pottery assemblages indicate strong cultural influence from the Vinča A culture during the early LBK period in southern Transdanubia (Marton, Oross 2012). Nándor Kalicz (1994. 72) had already pointed out that Vinča wares could be distinguished in the ceramic assemblages from some of the region's early LBK settlements. The preliminary assessment of the pottery finds from Alsónyék and Tolna-Mözs conclusively proves the exis- 
tence of a contact zone and cultural interaction between the two cultures. ${ }^{4}$

\section{The Sopot culture}

A Sopot culture site was identified about $1 \mathrm{~km}$ east of the large excavation area at Alsónyék (Fig. 2). Twenty burials and the remains of what was possibly an enclosure came to light at this site of the Sopot culture, 5 whose relation to and contact with the Lengyel culture is one of the key issues in Hungarian Neolithic studies. Very little was known about the Sopot cul-

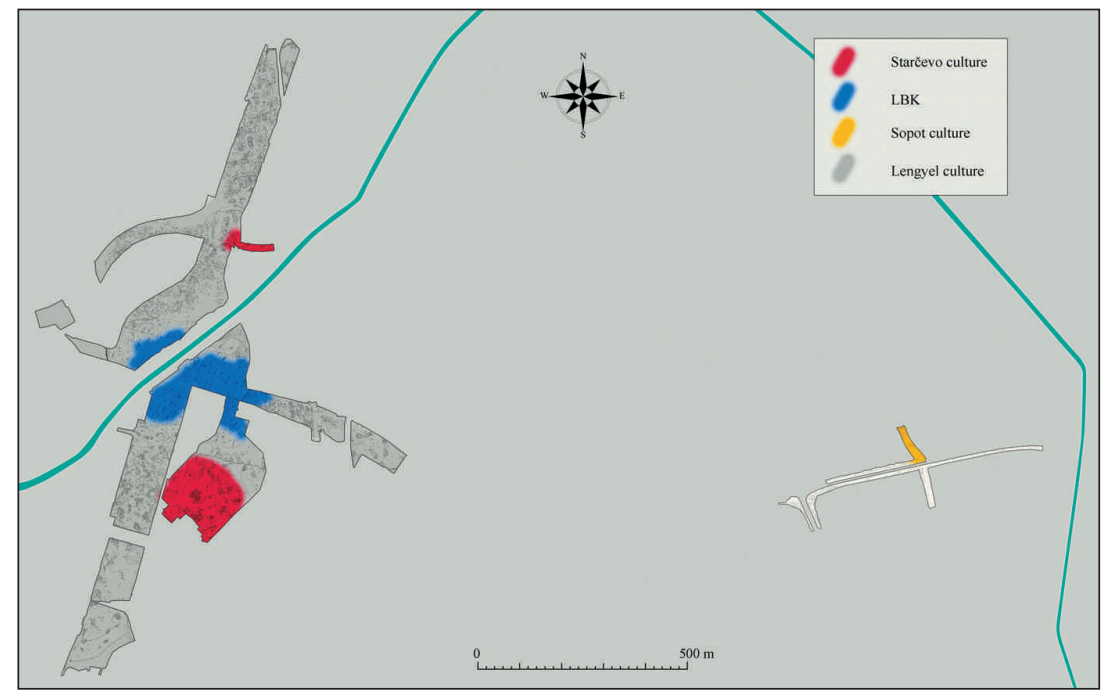

Fig. 2. Spatial distribution of Neolithic cultures at Alsónyék-Bátaszék.

ture in Hungary, even though our knowledge has grown considerably since the 1960s and 1970s, when the culture's first sites were identified. No more than three sites were known at the time: one of these was Bicske in Fejér County; the other two were Hidas and Izmény, both of which lie fairly close to Alsónyék (Kalicz, Makkay 1972). Finds of the eastern Transdanubian variant of the Sopot culture, characterised by a slightly differing artefactual material, have since been found also in south-western Transdanubia, in part from the excavations at Becsehely and in part from a series of sites in Zala County investigated during the salvage operations preceding the construction of the M7 motorway (Horváth, Kalicz 2003; P. Barna 2007). These sites share numerous similarities with the Brezovljani group of the western, Slavonian branch of the Sopot culture (P. Barna 2011.31). Large settlements of the culture can be found at Fajsz-Garadomb and Fajsz-Kovácshalom on the left bank of the Danube. Burials and the remains of possible buildings were uncovered at the former. 6 The tell site at Fajsz-Kovácshalom has been surveyed and systematically cored (Bánffy 2003). Dated to the transition between the Middle and the Late Neolithic, Sopot culture was assumed to have played a crucial role in the emergence of Lengyel culture as the medium and transmitter of southern elements (Kalicz, Makkay 1972. 12; Regenye 2002.32). Recent studies suggest that the Sopot and formative Lengyel phases were per- haps partly contemporaneous (Kalicz et al. $2007 b$. 44-45). Until recently, virtually nothing was known about the culture's houses or mode of construction. The large-scale excavations conducted over the past decades have brought a welcome change in this respect, too. Large Sopot settlements have been investigated at Petrivente, Sormás-Törökföldek and Sormás-Mántai-dúló during salvage excavations along the planned route of the M7 motorway (Horváth, Kalicz 2003; P. Barna 2007). A systematic overview of the settlement features and houses uncovered at the latter two sites has been published by Judit $P$. Barna $(2009$; 2011), together with a typological classification of the Sopot and early Lengyel houses.

\section{Research on Lengyel architecture in Hungary}

The earlier settlement territory of the Central European LBK was populated by the Lengyel culture during the Late Neolithic of the Carpathian Basin. The Lengyel distribution reached its greatest extent by the late Lengyel period (Raczky 1974.209; Regenye 2007.381). Research on the Lengyel culture began over 120 years ago. Over 300 sites are known in Hungary, about one-half of which can be found in southern Transdanubia (Zalai-Gaál 2008.243, Abb.2). The Alsónyék settlement lies near the culture's emblematic sites such as Zengôvárkony, Mórágy-Túzkódomb and the eponymous site at Lengyel. The early excavations at Lengyel and Zengóvárkony ac-

4 Our discussion of the LBK material from Alsónyék is based on the finds from the areas excavated by the Institute of Archaeology of the Hungarian Academy of Sciences.

5 The assessment of the finds is currently in progress. We would here like to thank János Ódor for kindly allowing the publication of the site and its finds.

6 The site was investigated between 2006 and 2008 as part of a collaborative research project between the Institute of Archaeology of the Hungarian Academy of Sciences and Tübingen University. The excavations were directed by Eszter Bánffy and Jörg Petrasch. 


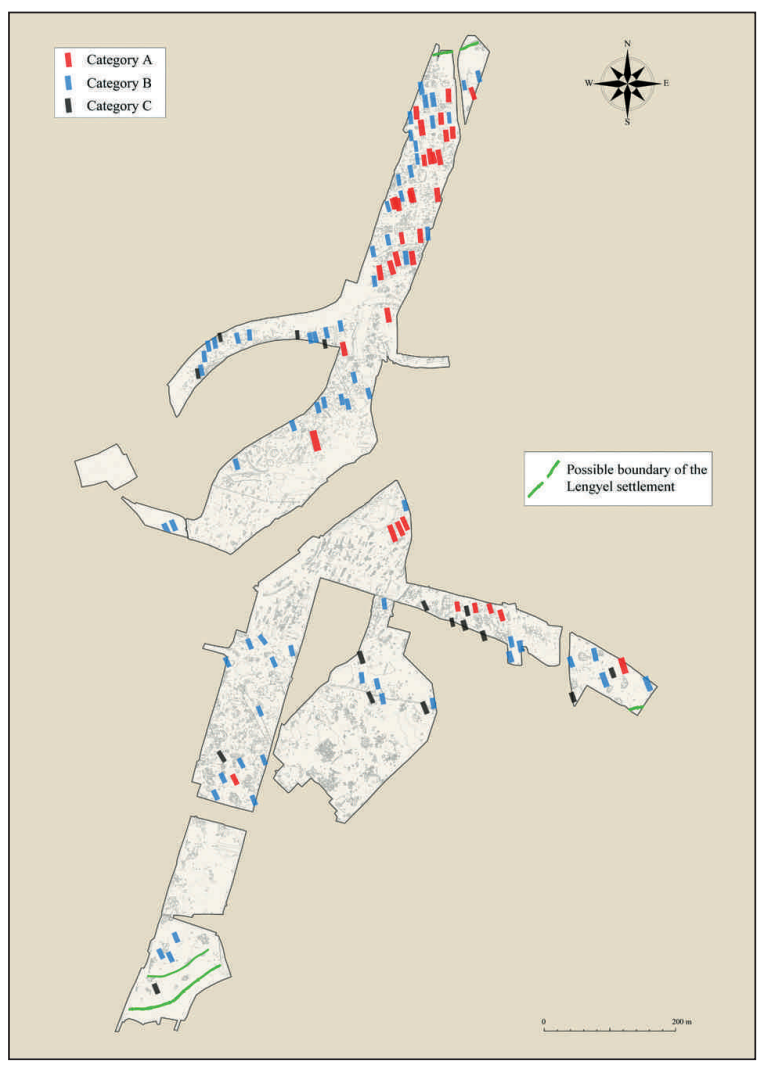

Fig. 3. The Lengyel settlement at Alsónyék-Bátaszék with the distribution of the timber-framed houses and possible boundary of the settlement.

quainted the archaeological community with the culture's material heritage, its burial customs and the grave goods deposited in the burials.

The beginning of research on the Lengyel culture is synonymous with Mór Wosinsky's activity in the late $19^{\text {th }}$ century. He excavated 'narrow habitations' which he described as lowly hovels at the Lengyel site (Wosinsky 1885. 38). In his view, the 'habitations' included sunken pits whose sidewalls of daubed witling rose above the ground (Wosinsky 1896.31-49).

Wosinsky's excavations were followed by an upsurge of archaeological interest in the Lengyel culture during the 1930s, especially in southern Transdanubia, marked by a series of larger excavations and research projects, whose key figure was János Dombay. He investigated several sites in Baranya County, the most important of which were PécsváradAranyhegy, Villánykövesd and Zengôvárkony. The many features exca- vated at the latter site and the 368 burials uncovered during the site's investigation made Zengôvárkony into the period's best-researched archaeological site (Dombay 1939).

Based on the observation made during his excavations at Pécsvárad and Villánykövesd, Dombay believed that the dark, ashy patches forming straight rows visible on the surface represented former habitations, under which he discovered elaborate 'pit systems'. He concluded that these large pits, yielding a rich array of finds, were the remains of the sunken huts and outbuildings of the settlement's occupants. He interpreted the ashy levels mixed with charcoal and soot as the remains of the collapsed roof (Dombay 1958.58-69; 1959.69).

He made similar observations at Zengóvárkony. He carefully analysed the house remains, which inspired a series of elaborate reconstructions (Dombay 1960.156-192). The oft-quoted house plan, which for a long time was the single known above-ground, timber-framed building of the Lengyel culture, was uncovered at Zengóvárkony. As a matter of fact, the house plan represented not one, but three buildings, because the original house had been renewed twice. Taking the differing colour and composition of the fill of the postholes as his starting point, Dombay (1960.57-65, $A b b .17)$ attempted to distinguish the different building phases and made reconstructions of the building in each phase. Later, Pál Patay (1985) also devoted a study to the house plans at Zengôvárkony. He noted that the three houses had been built in the same architectural tradition. He was not wholly satisfied with the reconstructions

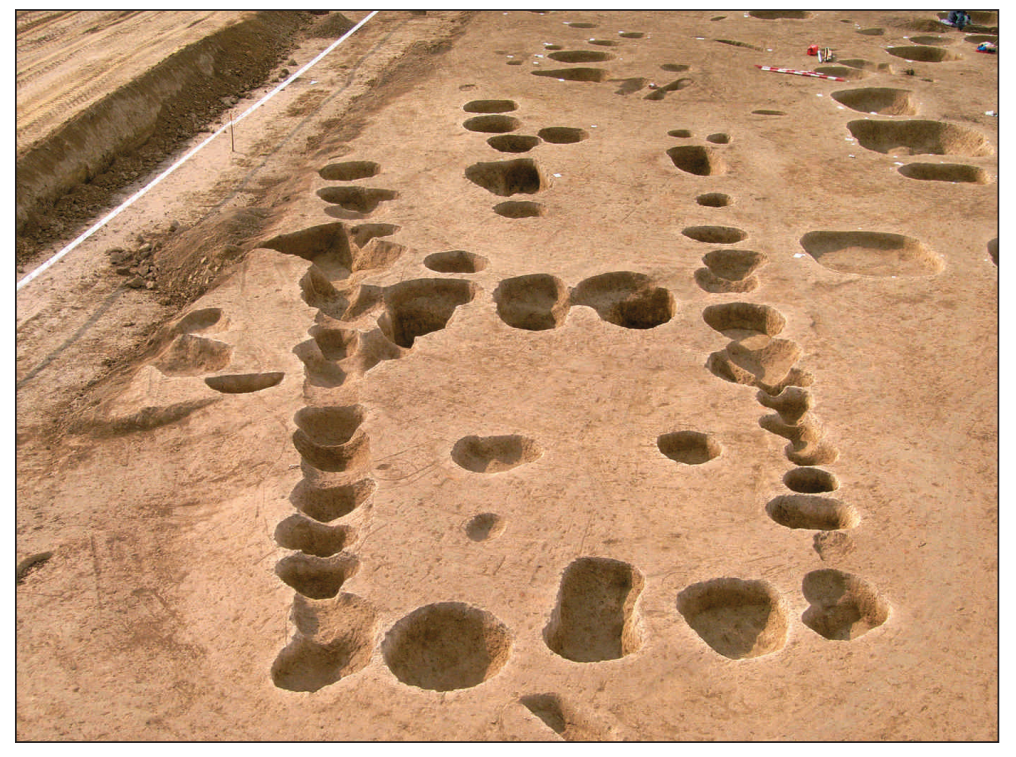

Fig. 4. Alsónyék-Bátaszék. House 2401, view from the north. 
proposed by Dombay and MüllerKarpe (1968.233, Taf. 188.M), and thus created his own version (Patay 1985.550 , note 15). We also revealed several successively renewed buildings at Alsónyék and found that the buildings became slightly larger with each renewal. Based on this observation, each of the three earlier reconstructions can be challenged on the grounds that the later buildings could hardly have been smaller than the initial one (Patay 1985.551, $A b b .1)$. It remains unclear with which occupation phase the buildings found at Zengóvárkony can be associated. According to Juraj Pavúk's (2003.464) chronologi-

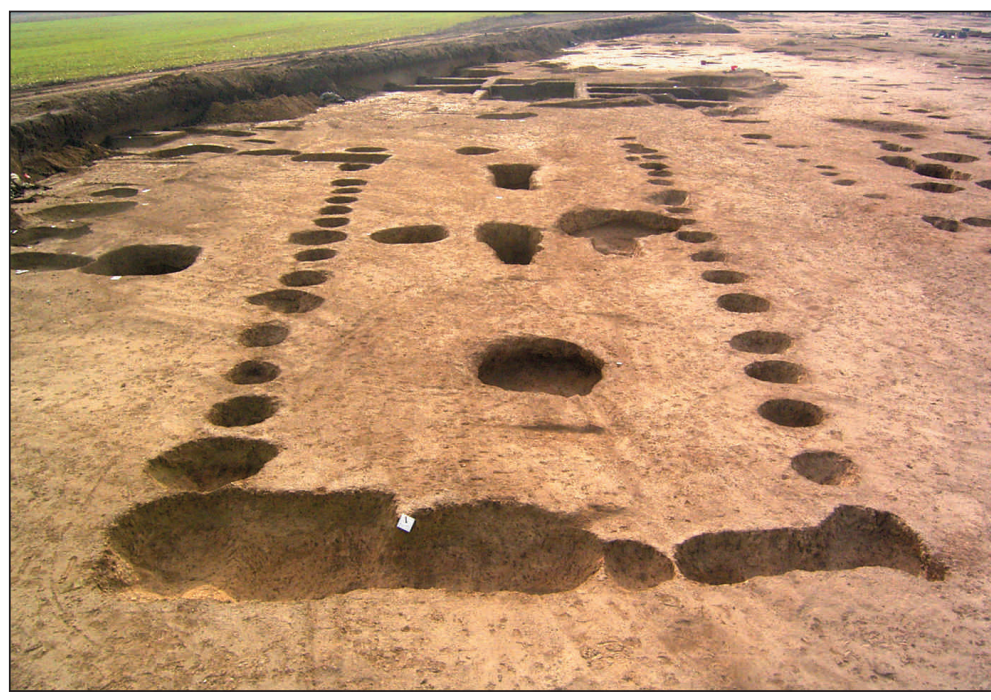

Fig. 5. Alsónyék-Bátaszék. House 7003, view from the north. cal framework, the house plans can be dated to the Lengyel I or Santovka phase.

Dombay's influence on later research can also be seen in Rezsố Pusztai's work, who in 1948 uncovered a 7 x $5 \mathrm{~m}$ large pit at Szemely, also in Baranya County, in whose central area he found a hard-beaten clay floor and a hearth. Quoting Dombay's observations from Pécsvárad and Zengóvárkony, Pusztai claimed that the round pits had been habitations and that this house type represented the domestic architecture of Lengyel culture (Pusztai 1956. 39-41).

Until the 1960s, research on Lengyel culture was largely restricted to south-eastern Transdanubia. Even so, the repeatedly renewed, timber-framed building found at Zengóvárkony remained the only one of its kind for a long time.

The investigation of the early Lengyel settlement at Aszód in Pest County was begun in the 1960s. The site lies on the north-eastern boundary of the Lengyel distribution, so its excavation offered insights into the culture's cultural contacts with other regions. The burnt remains of five wattle-and-daub buildings were uncovered. Lying at a shallow depth below the modern surface and greatly disturbed by ploughing, the houses were spaced some $30-35 \mathrm{~m}$ apart with no apparent pattern. The small buildings were outlined by the $8 \times 5 \mathrm{~m}$ and $6 \times 4.5 \mathrm{~m}$ patches of burnt debris. No postholes of the timber structure were identified. The floor level was indicated by hearths and the position of various artefacts. Nándor Kalicz interpreted the houses as buildings occupied by small nuclear families. Comparable surface-level houses with wattle-and-daub walls were known only from Csabdi, a settlement lying in the culture's eastern distribution (Kalicz 1985.15-20). In view of the fact that houses of this type were unknown in the entire Lengyel complex and that the finds from Aszód reflected contacts with the Tisza culture, Kalicz suggested that the origins of the architecture at Aszód should be sought outside the culture's distribution (Kalicz 2008.10, 13).

The next major discoveries were made in western Transdanubia in the late 1960s. In 1968, Mária Károlyi conducted a rescue excavation at JánosházaFürdődomb, where she uncovered an 'Early Copper Age residential building'. Károlyi noted the likeness between the round ground plan and various other elements of the house that she had excavated and the building uncovered earlier at Szemely. She reconstructed a small settlement with seasonally occupied buildings and dated the settlement to the Lengyel III period on the basis of the finds (Károlyi 1992.6-7, 78). Also on the strength of the find material, she interpreted a similar pit measuring $4 \mathrm{x}$ $10 \mathrm{~m}$ brought to light at Kisunyom-Nádasi tábla as a sunken house dating from the period between the Lengyel culture and the Balaton-Lasinja culture (Károlyi 1982.295-296). The sunken structures of this type in Austria and Moravia were recently discussed by Ângela Carneiro (2006.78) in her publication of the sunken feature at Mannersdorf an der March. Quoting also the structures uncovered by Károlyi in Hungary, she concluded that these features were probably workshops.

A few sunken buildings with a clearly discernible occupation level were discovered in Zala County du- 
ring the 1970s. Two of these structures were dated to the early Lengyel period (H. Simon 1987.7-8). A number of research projects in the 1980s and 1990s gave fresh impetus to archaeological investigations in Zala County (the Hahót Valley Project, the archaeological investigations related to the Little Balaton Reconstruction Project). The field surveys and excavations conducted during these projects yielded invaluable new data for the settlement patterns of the Lengyel culture, indicating a dense settlement network during the culture's early (Lengyel I) and late (Lengyel III) phase (Bánffy 1995a; 1995b; Bondár 1995). The above-ground, timberframed buildings of the Lengyel culture have not been found at these sites.

The story of the culture's architectural research continued in Veszprém County. In the early 1970s, Marietta Csányi and Pál Raczky uncovered a part of a building at the Veszprém-Felszabadulás út site. The

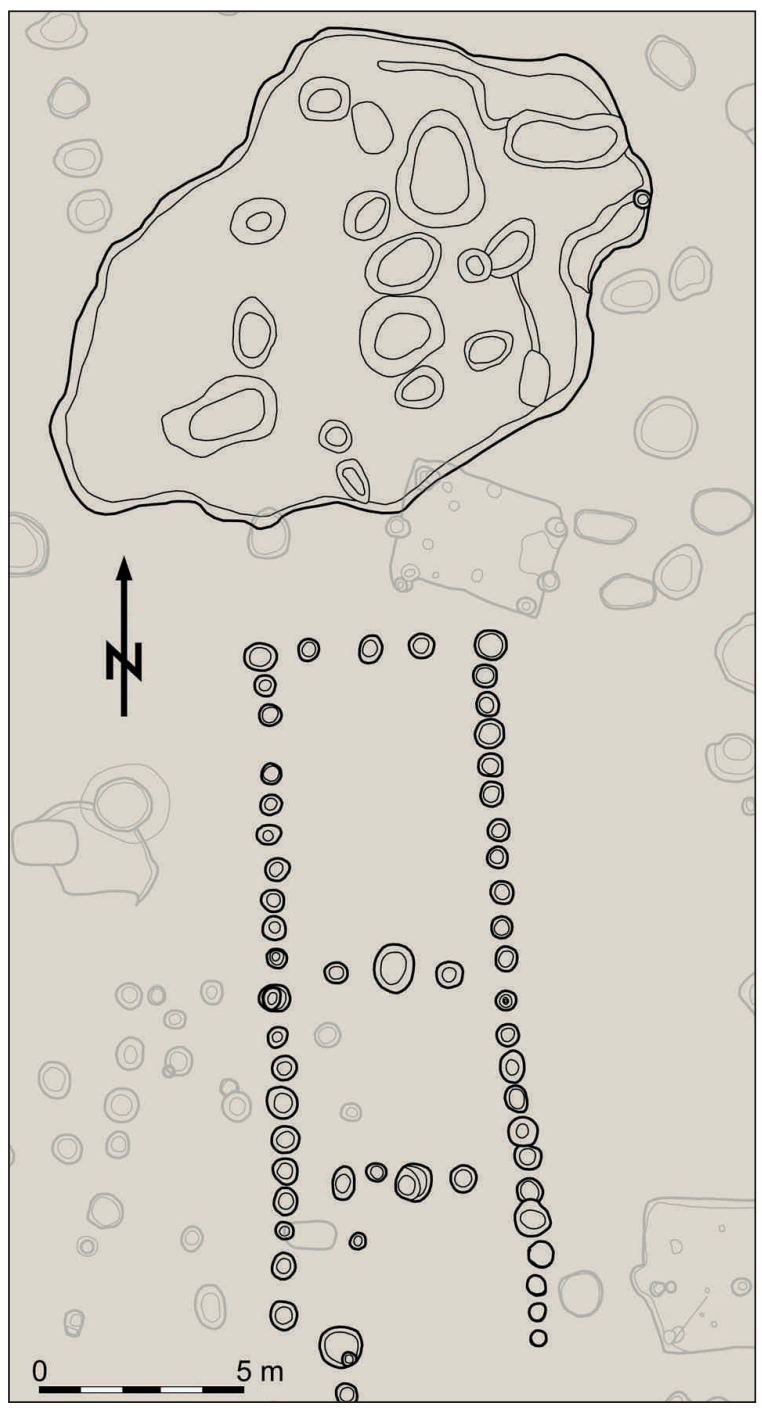

Fig. 6. Alsónyék-Bátaszék. Plan of House 498. large, north to south oriented building measuring $18 \times 9 \mathrm{~m}$ had an apsidal end. The $40-50 \mathrm{~cm}$ thick posts of the timber framework were dug into a 25$50 \mathrm{~cm}$ wide bedding trench. However, postholes were observed only along some sections and no more than a small part survived of the bedding trench for the apsidal end. The building had a floor of hardpacked yellow clay (Raczky 1974.186). The building remains unparalleled in Hungary. The other major contribution of the Veszprém site to Lengyel studies was that - through a minute comparison with the material from other sites - it allowed Raczky to distinguish the late Lengyel phase (Lengyel III) in the culture's Hungarian sequence (Raczky 1974.205).

Breaking the linear narrative of research history, a later excavation at the same site should be mentioned. In 2003, Judit Regenye investigated another part of the Veszprém site during a rescue excavation, which yielded important new data on the settlement patterns and architectural traditions of Lengyel culture. This was the settlement where the classic postframed houses of the culture were documented again, for the first time since the excavations at Zengóvárkony. Regenye (2004.25; 2007.381) had revealed nine surface-level, timber-framed houses, which she dated to the end of Lengyel II and Lengyel III. The large rectangular or slightly trapezoidal buildings were all built around a framework of upright timbers, indicated by the closely spaced oval posthole, which in some spots formed bedding trenchlike sections. The houses are all basically of the same type, although with slight variations. Most had an internal partitioning wall supported by two or three massive posts dug to a considerable depth and another heavy post in the middle of the southern end. The consistent lack of a southern wall suggested that this room was either open or porch-like, or that this wall had been of a flimsier construction whose posts had barely been dug into the ground. The posts providing the frame of the sidewalls of the southern room were in all cases driven deep into the ground, raising the possibility that they had perhaps also supported a second floor. Regenye (2004.29; 2007.386) quoted the buildings from Zengôvárkony and the houses from Santovka and Žlkovce assigned to Type 3a by Pavúk as the best analogies to the Veszprém buildings.

Other investigations in the Veszprém area focused on identifying the workshops of the Szentgál-Túzköveshegy flint deposits (Regenye 2000; 2001). Several smaller settlements were recorded which had been established for the protection of the mine and 
for exploiting its deposits. These settlements yielded buildings entirely different from the VeszprémJutasi út site. At Szentgál-Teleki-dúlő, for example, an irregular rectangular house plan with a row of postholes across its middle was uncovered after the removal of the burnt daub debris. The building's sidewalls were outlined by smaller postholes. The building's width conformed to the usual width of the large Lengyel houses, but its length was about one-half of the culture's standard norms. Similar buildings were found at Ajka-Pál-major and Városlőd-Újmajor, while debris of burnt daub was excavated at the Szentgál-Füzi-kút site; no post holes were found under the debris. Regenye contended that these structures and the similar buildings uncovered at Aszód, Tekenye, Zalaszentbalázs and in the distribution of the Moravian Painted Pottery culture indicated the existence of another house type, and suggested that villages with houses of this type represented another element in the Lengyel settlement network. She distinguished these villages from the more central, densely occupied settlement with large timber-framed houses that were engaged in specialised production or in the organisation of trade, which in her view was also reflected in the nature and spatial organisation of the settlement (Regenye 2004.31-32; 2007.395; 2011.63).

Our knowledge of Copper Age architecture was substantially enriched by new information recovered from the sites investigated during the salvage excavations preceding the construction of the M1 motorway and other major construction projects on the Small Hungarian Plain, first at Győr-Szabadrétdomb, Mosonszentmiklós-Pálmajor, Lébény-Bille-domb, Lébény-Kaszás-domb, Mosonszentmiklós-Egyéni-földek, Győr-Marcalváros-Bevásárlóközpont in GyôrMoson-Sopron County (Figler 1993; 1997; Németh 1994; M. Egry 2001; 2003) and later at Szombathely-Metro áruház in Vas County (Ilon, Farkas 2001). The buildings discovered at these sites have been analysed in detail (M. Virág 2004; 2005; M. Virág, Figler 2007). In addition to the house plans assigned to the Balaton-Lasinja/Ludanice culture, the remains of buildings with bedding trenches possibly dating to the late Lengyel period were also uncovered during the excavations at Gyốr-Szabadrétdomb and Mosonszentmiklós-Pálmajor. House 500 at Gyốr-Szabadrétdomb was a large, two-roomed building with an open porch. The building had a bedding trench and was divided into two rooms by a wall indicated by three posts. A large posthole for a massive beam supporting the roof was uncovered in both rooms (M. Virág, Figler 2007.347, 348, Fig.

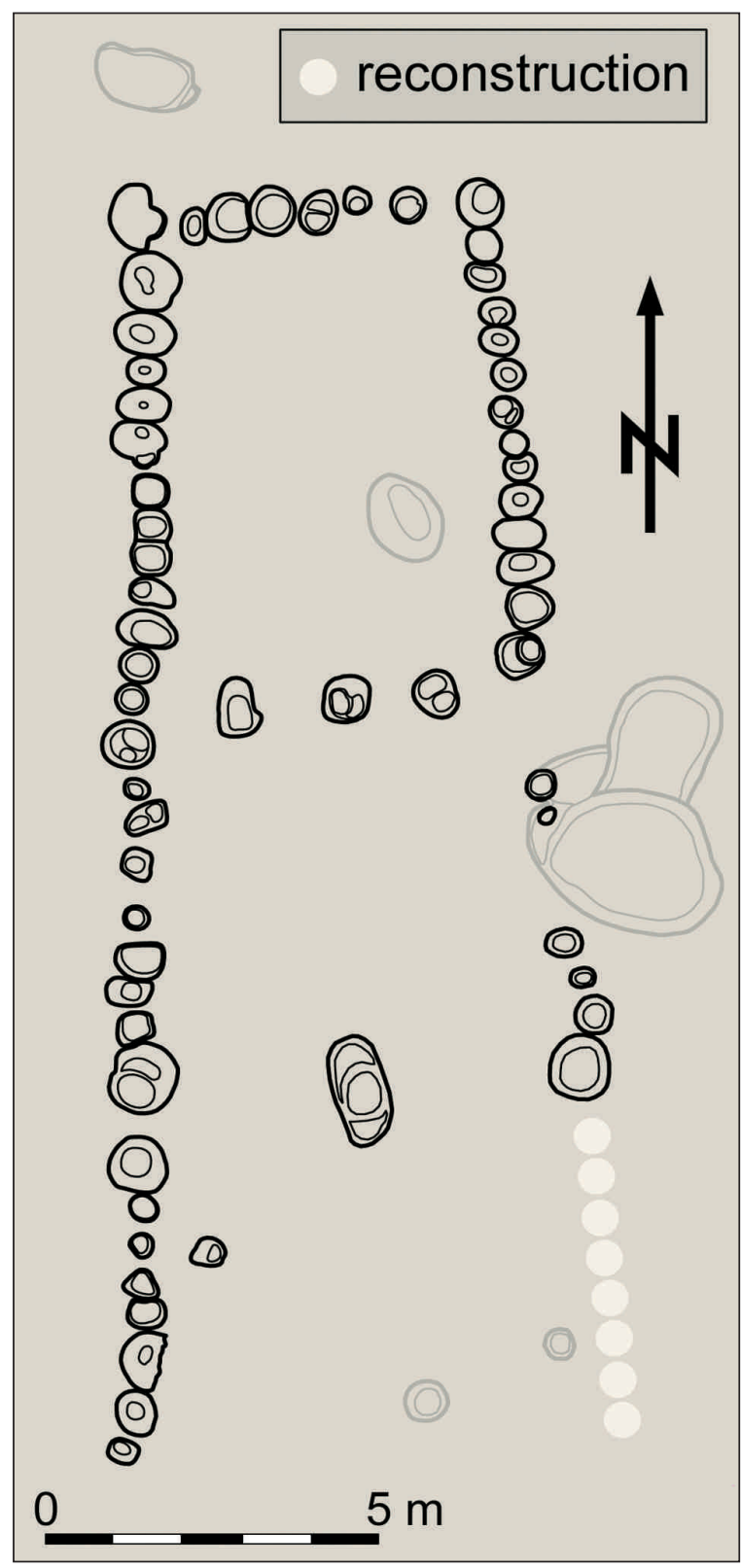

Fig. 7. Alsónyék-Bátaszék. Plan of House 7644.

2.2). This building resembled the houses reported from Veszprém-Jutasi út and the Slovakian ones assigned to the Lengyel II period by Pavúk, the only difference being that the latter lacked a bedding trench. This house plan at Gyôr-Szabadrétdomb can probably be dated to the beginning of the Lengyel III period (M. Virág, Figler 2007.350).

Several buildings with bedding trenches, differing from the house described above, came to light at the Gyôr-Szabadrétdomb and Mosonszentmiklós-Pálmajor sites. In the view of Zsuzsanna M. Virág and András Figler, the best parallels to these buildings are the house plans discovered at the late Lengyel/epiLengyel sites in Austria and the similar buildings of 
the Balaton-Lasinja period (M. Virág, Figler 2007. $350,352,357,358,360$ ). As the finds of both periods (late Lengyel and Balaton-Lasinja) were brought to light at these two sites, there is no conclusive evidence for dating the house to one or the other culture, as it is almost impossible to date the buildings on typological grounds alone without the support of stratigraphic data, radiocarbon dates and a clear association of finds with a particular building (Virág, Figler 2007.360).

Returning to south-eastern Transdanubia, research in the later $20^{\text {th }}$ century was principally concerned with the assessment of the enormous body of finds unearthed earlier. The over 600 burials found in south-eastern Transdanubia during previous and more recent excavations (Mórágy-Túzkốdomb) were discussed by István Zalai-Gaál (2001; 2010). The typological analysis of the finds and socio-archaeological analysis of the cemeteries brought major new insights regarding the period's social organisation and relative chronology in south-eastern Transdanubia. New Lengyel buildings did not come to light during more recent excavations, so studies of the region's architecture lag behind compared to other regions.

Following research by Zalai-Gaál (1990), the intensive survey and mapping of the Lengyel enclosures in Baranya County was begun (Bertók, Gáti 2011). In addition to a better knowledge of the structure, function and chronology of enclosures, the work by Gábor Bertók and Csilla Gáti also provided new information on the culture's settlement network, because settlements could be assumed near the enclosures. The remains of 16 enclosures of the Lengyel culture were investigated in Baranya County, using mostly non-destructive survey techniques. Four of the 16 sites identified through aerial archaeological photography were investigated in greater detail with a magnetometer survey and small sounding excavations. Two of these were the enclosures at Villánykövesd and Zengóvárkony, two of the sites excavated by Dombay. One interesting finding of the survey at Zengóvárkony was that the projection of the old excavation trenches onto the survey plan revealed that Dombay's trenches had all missed the enclosure, explaining why he had made no mention of it (Bertók, Gáti 2011.7, Abb. 5d). Another intriguing discovery was that the magnetometer survey also indicated the presence of what were probably large buildings inside the enclosure at the SzemelyHegyes I, Belvárdgyula and Szarkahegy sites (Bertók, Gáti 2011.10-11, Abb.7-8, 12,

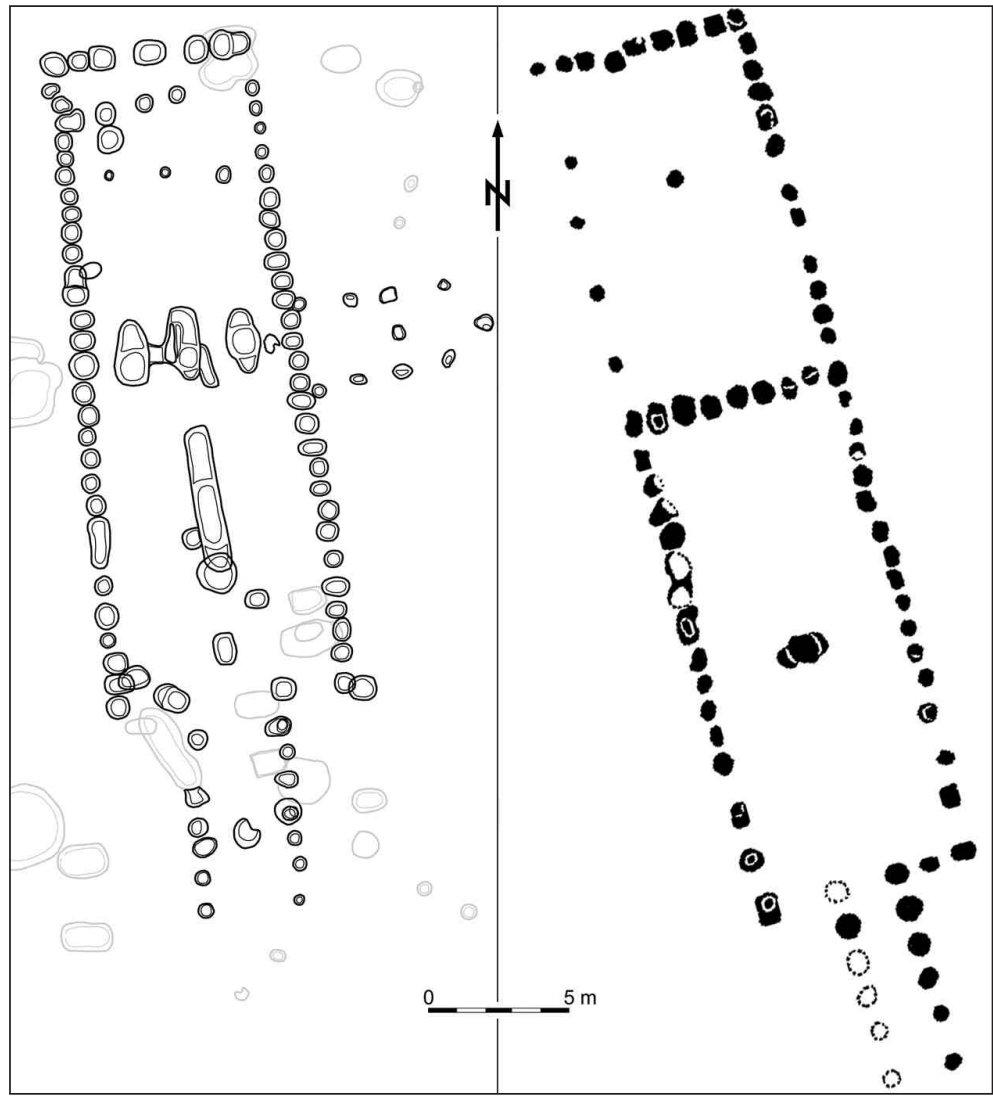

Fig. 8. Plan of House 6150 at Alsónyék-Bátaszék (left), House 52 at Žlkovce (right, after Pavúk 2003.Abb. 9.1).
13, 18-19, Abb. 13-14).

The large-scale excavations have opened up entirely new perspectives in the research of prehistoric settlements. These investigations have called for new approaches to the study of settlement size and settlement layout, as well as to how prehistoric societies were organised. The many new finds of above-ground, timber-framed houses have called for a re-assessment of earlier views. By this time it had become clear that the sunken structures/pits previously interpreted as residential buildings were temporary shelters or features used for various activities (e.g., $\mathrm{Ka}$ licz 2003.8; Raczky 2005.24; Pavúk 2003.464).

It must also be noted that several problems are encountered when interpreting the house plans discovered during salvage excavations. Very often, they are incomplete because some of the structural elements were 
not dug into the virgin soil and thus the surviving house plans are unsuitable for architectural reconstructions or for an assessment of the possible variations between various buildings and the differences in their architectural details. With the lack of a sufficient body of evidence, the reconstructions are strongly hypothetical. Also, despite the large area investigated, very little in the way of new information has come to light regarding the internal furnishing of houses.

The Lengyel period is characterised by a new architectural innovation compared to the preceding LBK period. One hallmark of the new architectural canon was the disappearance of the internal longitudinal rows of posts supporting the roof and a new roof construction. In the German terminology, this new roof structure is called 'Sparrendach' (von Brandt 1980.424, 497-499; Masuch, Ziessow 1985.64; Lichter 1993.61-63; Pavúk 2003.456, 466-467; Raczky 2005.26). In this new construction, the load of the roof was borne entirely by the side walls. Pavúk argued that the large post supporting a second storey made additional timbers unnecessary inside the house. In Pavúk's view, this architectural innovation was probably mediated to the Lengyel culture by the Vinča-Pločnik culture (Pavúk 2003.456, 466).

\section{The Lengyel settlement at Alsónyék}

The remains of at least 118 above-ground, timberframed buildings were uncovered at the Alsónyék site (Fig. 3), ${ }^{7}$ and additional buildings probably lie in the still unexplored area beyond the investigated section of the motorway's planned path. As a comparison, Pavúk listed a total of 150 buildings from Slovakia, which he assigned to various phases of his Lengyel sequence (Pavúk 2003).

About one-third of the house plans (Fig. 3) uncovered at Alsónyék survived with indications of the structural elements and their foundations virtually intact (Category A, 35 houses). The majority of the house plans, however, were incomplete, but were well fairly preserved and thus the original building could be reconstructed in many cases (Category B, 67 houses). The remaining buildings were houses of which only a few characteristic elements survived to indicate their presence (Category C, 16 houses). ${ }^{8}$ These elements include the deep and sturdy foundations of partitioning walls and the remains of en-

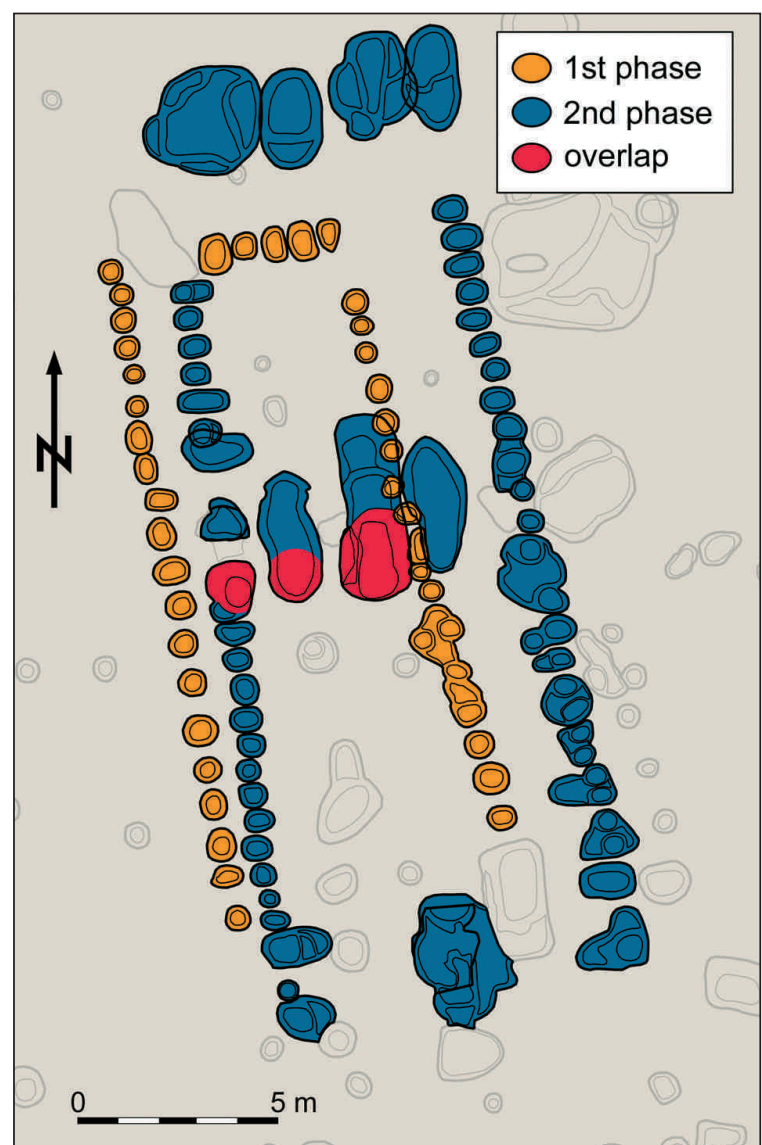

Fig. 9. Alsónyék-Bátaszék. Plan of Houses 6132 and 6133.

trances. Obviously, the latter could not be included in the architectural analysis, but they contribute useful information regarding the layout of the settlement. The many postholes would suggest that there had once been considerably more buildings on the settlement than suggested by the surviving house plans, but we saw no sense in including hypothetical houses on the map. However, the differences in the preservation of the buildings as reflected in the three categories (A-C) clearly show that not only certain structural elements, but also entire houses can perish during the salvage excavations preceding large-scale construction projects owing to the mechanical removal of the topsoil. The partially surviving house plans are insufficient for studying possible architectural innovations and variations, which could indicate changes in the architectural traditions of a site or period.

The majority of the house plans suitable for a detailed architectural analysis (complete houseplans of Category A) came to light in the northern part of the

\footnotetext{
7 The exact number of buildings was not known at the time the preliminary reports were published (Zalai-Gaál, Osztás 2009.45; Gallina et al. 2010.12).

8 Similar categories were used in the assessment of the buildings of the LBK settlement at Balatonszárszó-Kis-erdei-dúló (Oross 2008).
} 
investigated area, where we found closely spaced buildings, many of which had been repeatedly renewed. There were 43 house plans in this area, most forming rows, although we had no way of establishing which buildings had been contemporaneous. The area was relatively densely and evenly built up in the northern and eastern trenches extending from the planned motorway. The southern part of the area appears to have been more loosely occupied. At the same time, a visible decline in occupation intensity could be noted in two areas: one in the central area of the excavated area, where the LBK settlement had been established, and the other in the south-eastern area, where the Starčevo settlement lay, where we did not register any traces of a Lengyel occupation. The remains of the Lengyel settlement could be documented across almost the entire part of the excavated area: it was $c .1500 \mathrm{~m}$ long from north to south and $800 \mathrm{~m}$ wide from east

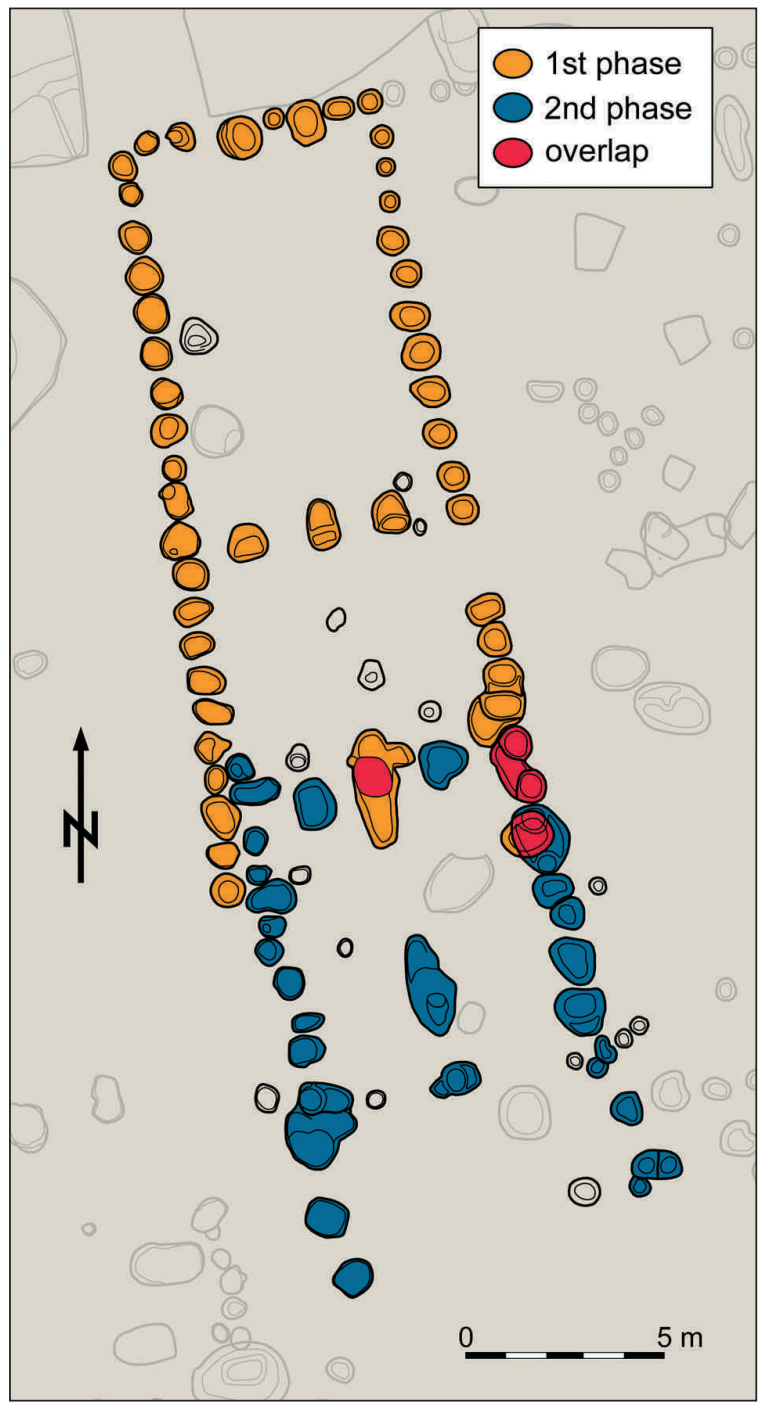

Fig. 10. Alsónyék-Bátaszék. Plan of House 4400, a renewed building. to west. The site's estimated size is approximately 80ha (Fig. 2).

The houses at Alsónyék were all large, post-framed buildings with one or two internal partitioning walls and an open porch on the southern side. We found no other types of residential buildings or sunken structures used for various activities. The houses all had a uniform north-north-east to south-south-east alignment, with slight variations across the entire settlement. The length of the buildings, including the porch, generally ranged between $14 \mathrm{~m}$ and $22 \mathrm{~m}$, although a few were longer. Their width varied between $6 \mathrm{~m}$ and $8 \mathrm{~m}$. They had rectangular or slightly trapezoidal ground plans, the sole difference between them being one of size, as the structures were virtually identical. The frames of the walls were indicated by densely spaced postholes, a feature noted at Santovka, Žlkovce and Veszprém. The postholes for the massive timbers of the wooden framework were sometimes dug at an angle, a practice also observed at Veszprém and the Lengyel houses in Slovakia (Pavúk 2003; Regenye 2004; 2007). The northern wall generally had five or seven posts, with the occasional building having nine. Pavúk has pointed out that the northern wall of the houses assigned to Type $3 \mathrm{a}$ at Žlkovce were consistently constructed with seven or nine posts and that the partitioning walls usually had the same number of posts as the northern wall (Pavúk 2003.459). At Alsónyék, however, we often found northern walls with five posts, while the partitioning walls were usually indicated by three very deep postholes (Figs. 5-10). The long walls were outlined by closely spaced round and oval postholes, whose number varied between 20 and 30 . In some cases, the postholes had a more irregular or larger oval form and formed smaller bedding trenchlike sections, as at Veszprém (Figs. 4-5; Regenye 2004.29) and in the case of the Lengyel houses in Slovakia (Pavúk 2003). Some houses had a bedding trench on the western side (although with few postholes inside), while others appeared to have a bedding trench for the northern wall (Gallina et al. 2010.14-15, Fig. 7, Pl. 70.17). One house plan had features resembling a bedding trench interrupted by gaps along both long walls (Gallina et al. 2010.71, $P l$. 18.2). During the removal of the upper humus layer, we often found that the edges of the soil marks indicating postholes were contiguous.

The Alsónyék houses were divided into a larger northern and a smaller southern or middle room by an inner partitioning wall. A similar sized porch often adjoined the smaller southern room, making the 
building three-roomed. The posts of the porch were usually dug to a slightly shallower depth than the timbers of the walls and it was therefore difficult to determine how large these additions had been because their traces were not always well preserved. In some cases, however, we were able to accurately establish that they were roughly the size of a room (Fig. 7). The porch was open, at least in the sense that there was no indication of a more massive wall with deeply dug posts. However, possible traces of less deeply dug posts may have perished when the topsoil was removed prior to the excavation. The entrance to the houses probably lay on the southern side. Our preliminary assessment indicated that the houseplans at Alsónyék were remarkably uniform and it seems likely that the architectural practices were similarly consistent. Some variability can be noted in the construction of the porch: one type has the porch separated from the second room from the north by a regular partitioning wall and the building thus has the semblance of a three-roomed structure (Fig. 6). Another type is characterised by the presence of a massive post at the house's southern end and the continuation of the two long walls beyond the line of this post (Figs. 7 and 10). The latter type is typical for the buildings of Type $3 \mathrm{a}$ in Slovakia and most of the buildings uncovered in Veszprém (Pavúk 2003.461; Regenye 2004). Yet a third type also has a narrow entryway (Fig. 8). The latter is represented by several houseplans at Alsónyék, which are slightly larger than the other buildings, but are no different otherwise regarding their other structural elements. Described as Bau mit Eingangskorridor by Pavúk (2003.462), the buildings of this type unearthed at Žlkovce (assigned to Type $3 \mathrm{~b}$ ) were believed to have a special function in view of their location (Pavúk 2003.461) because they lay inside the central enclosure, farther from the densely occupied settlement section, and were thus initially assumed to have been the settings of rituals or the residence of an economic and political elite, and thus a possible reflection of social ranking (Pavúk 1991. 356). In his latest study, Pavúk (2003.460) contended that these buildings had been the settings of ritual activities. Six buildings of this type were unearthed at Žlkovce. Although their exact chronological position remains unknown, Pavúk assumed that a building of this type had stood in each occupation phase of the settlement. He quoted a building found at the Gomolava site of the early Vinča-Pločnik culture as the best parallel to this type and regarded the similarities between the two as additional proof of the role played by Vinča culture in the emergence of Lengyel culture (Pavúk 2003.462-463). At Alsónyék, the buildings with an entryway do not appear to have been set apart from the other houses. Their exact chronological position remains unknown for the time being. They may have originally formed a separate cluster, but this is not apparent from the plan of the site, which shows a densely built-up settlement. However, given their size, we cannot exclude the possibility that these buildings were perhaps an expression of social inequalities (Siklósi 2010.41). Buildings with an entryway have been reported from the Hulín-Pravčice-Višňovce site in Moravia (Kalábek et al. 2009.248-249, Fig. 7; Dobeš et al. 2010.58, Abb.3); their large dimensions perhaps support an interpretation along these lines.

The renewal of a house on the same spot could be noted in several cases in the northern part of the excavated area (Fig. 9). The more sturdy construction of the partitioning wall and the northern wall can probably be explained by the enlargement of the buildings. In terms of its structure, the new building did not differ from the earlier one, save in its dimensions, reflecting the intention to increase the building's size. The preservation of the earlier structure could be documented in the case of one building to which an extra room was added at the southern end (Fig. 10). The house plan reveals that the open porch on the southern side had been walled up, creating a new partitioning wall between the new room and the entrance, which was virtually reproduced. The practice of renewing houses on the same spot was also observed at Zengôvárkony and Veszprém (Dombay 1960; Regenye 2004).

Virtually nothing is known about the internal furnishing of Lengyel houses and the functions of the different rooms. Very few houses had burned down and even fewer had preserved some part of their furnishings. Two notable exceptions can be cited from the Nitra and Budmerice sites. A hard-burnt clay layer was found at the latter, which Pavúk (2003.455-456) interpreted as the remains of a second storey or the ceiling. Obviously, the floor level of the houses may have been destroyed by later intrusions and ploughing. Very often, we found large chunks of burnt daub directly under the plough zone. In a few cases, we uncovered burnt daub fragments, especially in the large postholes of the partitioning walls, perhaps an indication that the house had perished in fire. We also found burnt daub fragments in some spots and, in one case, we found intact vessels amidst the remains of what we assumed to be a burnt wall section (Fig. 11). Burnt daub fragments regularly occurred in the fill of the large refuse pits, 


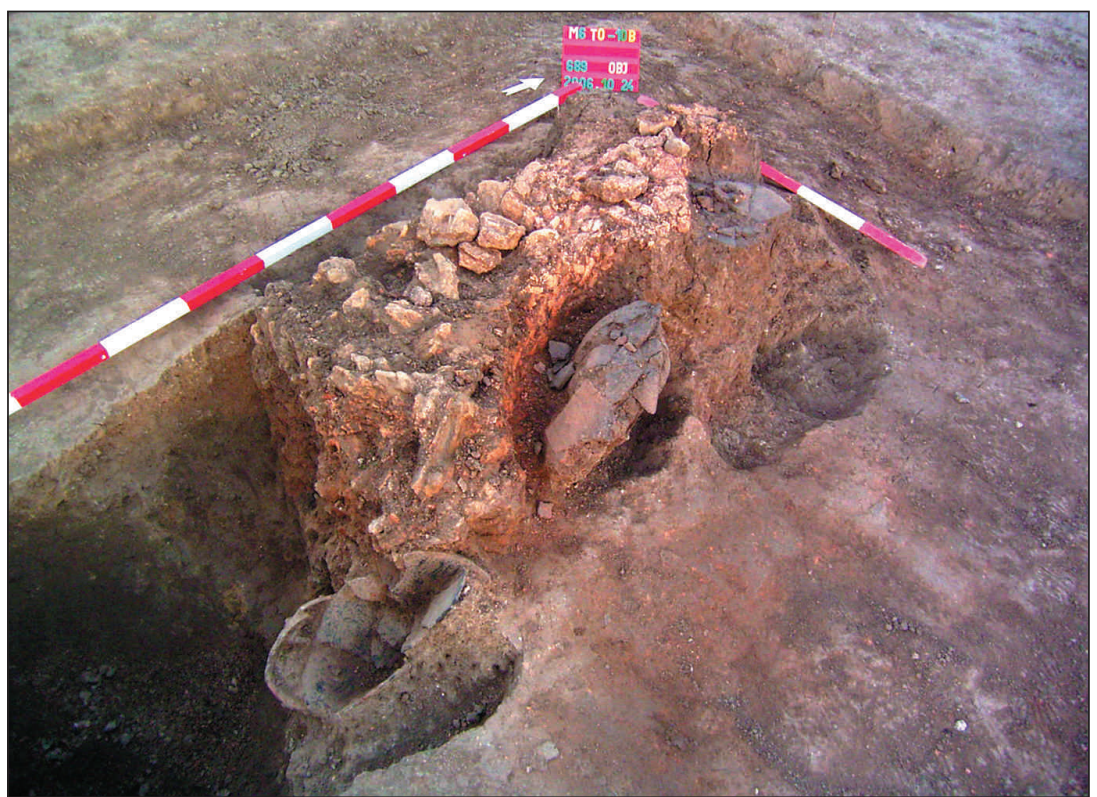

Fig. 11. Alsónyék-Bátaszék. Burnt debris of a Lengyel building with vessels in situ.

providing additional proof that some structures had been destroyed by fire and, also, that the rubble had been cleared away, i.e., that the occupants had kept the house areas clean.

The best architectonic parallels to the houses uncovered at Alsónyék come from nearby Zengôvárkony and the buildings excavated at Veszprém, and they also share numerous similarities with Pavúk's Type $3 \mathrm{a}$ and $3 \mathrm{~b}$, even though the latter are usually larger and have a rectangular ground plan, while the Alsónyék buildings are smaller and slightly trapezoidal. House plans of Type $3 \mathrm{~b}$, buildings with an entryway, have also been found at Alsónyék. However, there is one major difference between the houses of Type $3 \mathrm{a}$ and $3 \mathrm{~b}$ in Slovakia and the buildings at Veszprém and Alsónyék, namely the lack of a heavy post in the longitudinal axis of the innermost room, a feature typical of the Slovakian house plans which Pavúk (2003.460-461, Abb. 7-9) believes supported a second storey (ibid. 456). We do not want to take a definite stand concerning a possible second storey at this point, because in order to assume the existence of a second storey based on differences in the depth of postholes (Regenye 2004.29) requires a minute analysis of an enormous body of data. However, a few preliminary remarks can be made. A large posthole was found inside the Type $3 \mathrm{a}$ houses at both Žlkovce and Santovka, and while these were not always located in the centre of the room, they were positioned along the building's longitudinal axis ( $\mathrm{Pa}$ vúk 2003.461, Abb. 8). The same feature was recorded in the buildings at Hulín, a more recently inves- tigated site (Kalábek et al. 2009.248-249, Fig. 7), where several large postholes were uncovered along the axis of some houses, especially the larger ones such as House 45, an exceptionally huge building. One of the buildings uncovered in Veszprém had two postholes along the building's axis, probably for supporting the roof (Regenye 2004.43, Fig. 18). The currently available scanty evidence does not provide conclusive proof of the existence of a second storey/loft in the Lengyel buildings, and it is therefore possible that together with the middle posts of the partitioning wall, these posts had also played a role in supporting the roof structure. Since large posts of this type did not occur in the inner rooms of the buildings at Alsónyék, the presence of a second storey/loft above these rooms can be rejected. The single large posthole along the building's axis was found in the centre or the end of the porch-like southern room (Figs. 9-10), making it unlikely that this post had supported an upper storey or loft. It seems more likely that it had a static function. It is possible that, together with the central post of the northern wall and the partitioning wall, it supported the roof, a possibility suggested also by the fact that the central posts of the northern wall and the internal partitioning wall(s) were usually larger and dug deeper than the other ones. Obviously, a reconstruction along these lines can be confirmed or dismissed only after a minute analysis of the available data. Nonetheless, the preliminary architectural assessment of the buildings uncovered at Alsónyék suggests that there were no major changes in architectural practices during the settlement's occupation. The house plans at the site and their architecture reflect a fairly uniform and consistent practice. It would appear that certain standard procedures were followed in house construction which remained virtually unchanged during the settlement's life-time.

One of the crucial issues remains how the chronological position of the houses relative to each other can be determined. In other words, how can we securely identify the finds which can be associated with a particular house and which pits and other featu- 
res can be linked to one or the other building? How can we date individual buildings? In some cases, we found large pits extending along the northern wall which can in all likelihood be associated with the building (Fig. 6). Some of these pits, dug into each other, formed a ditch extending parallel to an entire row of buildings in some areas of the site. These pits were probably borrowing pits, opened when the house was built and later filled with household refuse (Fig. 12). Their enormous size raises the possibility that they can be linked to several contemporaneous houses, and thus - in addition to the data from archaeometric analysis - the superposi-

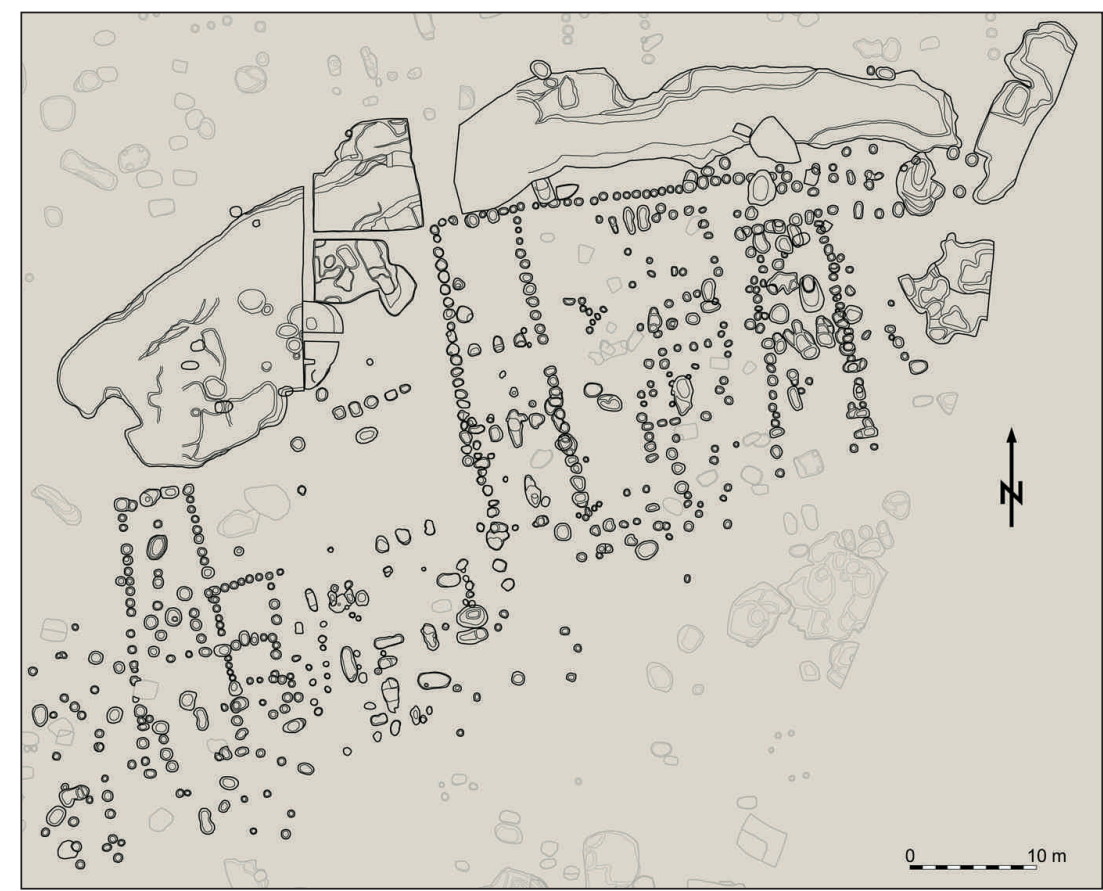

Fig. 12. Alsónyék-Bátaszék. Row of Lengyel houses with borrow pits dug into each other. tions, a minute examination of the site plans and comparison of various features of the find material can shed light on diachronic changes in the settlement's layout.

The Lengyel settlement probably continued in almost all directions beyond the excavated area. How can we determine the boundaries of such a large settlement? To answer this question, we considered the following points: the settlement extended to the eastern edge of site M6 T0 46 towards the west, where we found Lengyel burials and two timberframe buildings which could be confidently assigned to the Lengyel culture (Fig. 3; Majerik et al. 2010). A nearby hill limited the settlement's expansion in this direction. We uncovered a few ditch sections lying far from each other in the northern, eastern and southern ends of the excavation trenches, which we interpreted as marking the possible boundaries (Fig. 3). The ditch (Feature 4305) extended along the entire width of the motorway's planned path in the northern part of the excavated area. Only a small section was found in the east (Feature 2218), while two parallel ditch sections were identified in the southern part of the excavated area. The section of the ditch indicated a V-shaped structure, $2 \mathrm{~m}$ deep and $1-1.5 \mathrm{~m}$ wide. We did not find any postholes in the bottom of the ditch or any traces suggesting a palisade or structure on the inner side of the ditch. The fill, the dimensions and the presence of certain structural elements suggested that these sections were part of the same ditch. An exact counterpart of the structure perpendicular to the ditch is known at Sormás-Törökföldek, where it was interpreted as a wooden bridge (P. Barna 2010.97, 114, Fig. 8.1).

One oft-encountered problem in estimating the size of the community occupying the settlement is that population estimates based on the number of houses (and their inhabitants) is often at variance with the number of excavated burials. Very often, the number of burials is quite low compared to the houses uncovered during the excavation of extensive areas (Raczky, Anders 2006.25). The obvious question, then, is where did the occupants bury their dead? At Alsónyék, we found 2359 Late Neolithic burials which formed groups, the smallest of which contained 25 to 30 burials, the largest as many as 100 . The latter reflect the continued use of a burial ground or perhaps a change in mortuary customs. A few solitary graves were also uncovered, some of which lay on the site of former houses and occasionally formed smaller clusters. The burials reflected a strict burial rite: the deceased were aligned east or west with the face to the south and they were laid to rest in a contracted position. One element of the Lengyel burial rite, graves containing some sort of a wooden structure, was first observed at the Alsónyék site. Compared to the usual oval or oblong grave pits, these graves were rectangular, larger than average and dug to a greater depth. Most of the grave pits 

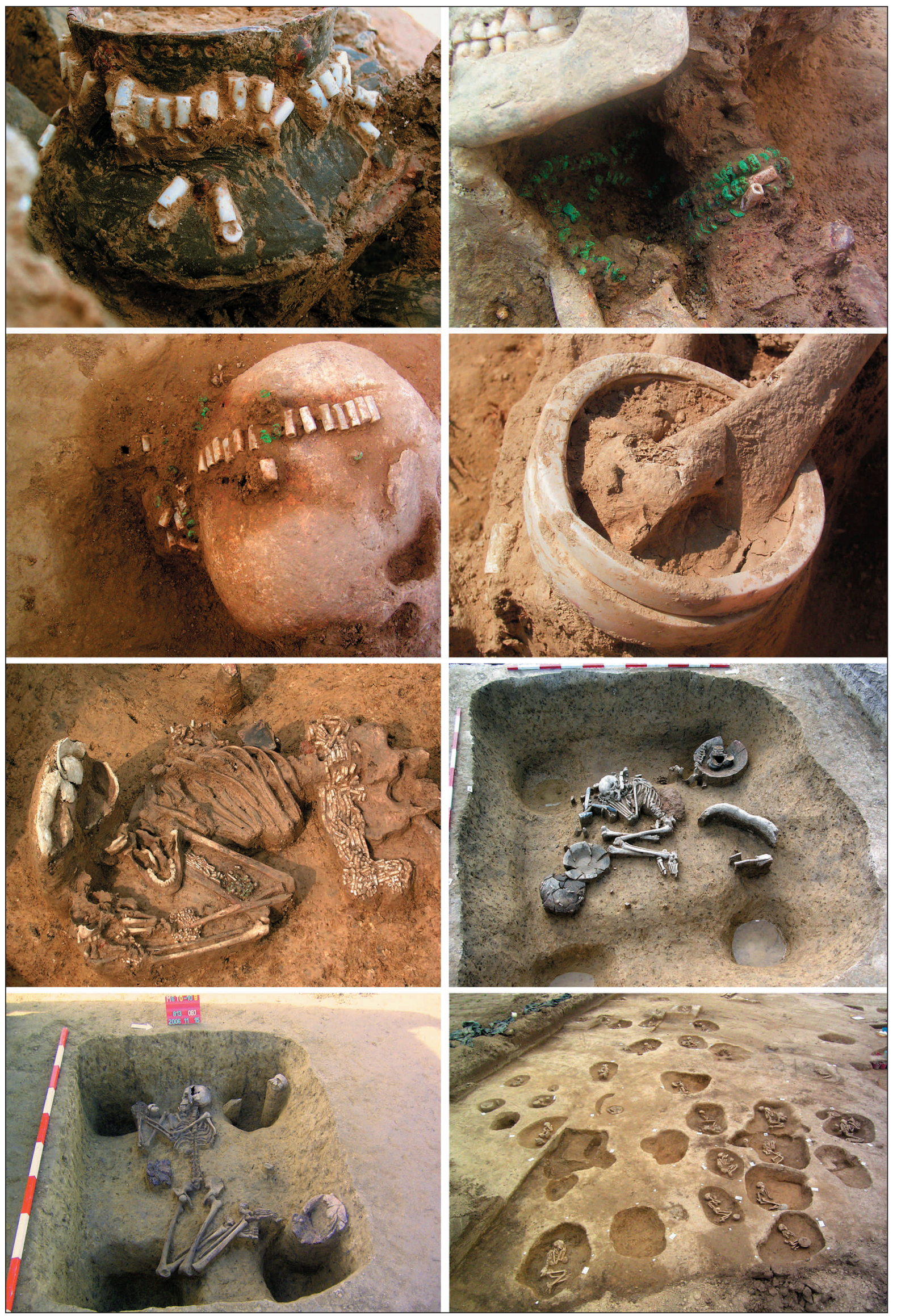

Pl. 2. A selection of burials and grave goods from Alsónyék-Bátaszék. 
measured $2 \times 2 \mathrm{~m}$ and had a large posthole in each corner, indicating the presence of a wooden bier or funerary structure erected over the burial (ZalaiGaál et al. 2012). The rich variety of grave goods costume adornments, jewellery articles, prestige items and other artefacts reflecting social status suggests that these graves can be regarded as those of the community's high-status members, and can thus be seen as a reflection of early social ranking (Pl. 2). About 100 burials of this type were uncovered. The preliminary anthropological assessment of the skeletal remains revealed that men and women were buried in these graves in roughly equal numbers.

The Lengyel settlement of Alsónyék is unique among the culture's known sites and represents a flourishing period in the life of the culture. During its occupation, the settlement grew into a regional centre of the type noted at Zengôvárkony, eclipsing the smaller settlements of the dense settlement network. The assessment of the artefacts and analysis of the pottery, lithic finds and copper and shell jewellery from the graves will take several years. Little can be said at present about the settlement's internal chronology. The preliminary assessment of the grave goods indicates that the cemetery was in use from the south-eastern Transdanubian Lengyel Ib period. Most burials yielded material typical of the Lengyel IIa1-2 period. The architectonic features of the houses and their resemblance to the buildings uncovered at Veszprém and the Lengyel sites in Slovakia indicate that the site was occupied continuously during the Lengyel II period.

\section{ACKNOWLEDGEMENTS}

We would here like to thank all participants in the excavations for their conscientious work. We are greatly indebted to the conservators and to our colleagues who provided invaluable assistance in cataloguing, drawing and photographing the finds. Special thanks are due to Mária Bondár, Melinda Vindus and Balázs Mende, who were a source of constant encouragement, and to our colleagues who participated in the assessment of the site and its finds: Erika Gál, Kitti Köhler, Tibor Marton, Éva Nyerges, Krisztián Oross, Gábor Serlegi and Krisztina Somogyi. We would also like to thank Zsolt Réti for preparing the illustrations. Finally, we are grateful to Mihael Budja for inviting us to participate at the Neolithic Seminar.

\section{References}

P. Barna J. 2007. A new site of the Lengyel Culture in Sormás-Török-földek (County Zala, South-Western Transdanubia). In J. Kozłowski and P. Raczky (eds.), The Lengyel, Polgár and Related Cultures in the Middle/Late Neolithic in Central Europe, Kraków: 365-380.

2009. A Sopot kultúra házai és települése SormásMántai dưlố lelőhelyen. Zalai Múzeum 18: 11-27.

2010. Sormás-Török-földek. Településtörténeti áttekintés II. A késố neolitikum. Zalai Múzeum 19: 93-115.

2011. Adatok a dunántúli késő neolitikus háztípusokhoz. A Sopot- és a korai lengyeli kultúra házai Sormás- Török-földek lelóhelyen. Beiträge zu spätneolithischen Haustypen in Transdanubien. Häuser der Sopotund der frühen Lengyel-Kultur am Fundort SormásTörök-földek. Móra Ferenc Múzeum Évkönyve - Studia Archaeologica XII: 31-45.

Bánffy E. 1995a. Neolithic and Copper age settlements at Hahót and Zalaszentbalázs (Zalaszentbalázs-Pusztatetô, Hahót-Szartóri I-II). Antaeus 22: 35-50. 1995b. Early Chalcolithic settlement at ZalaszentbalázsSzőlőhegyi mezô. Antaeus 22: 71-108.

2003. Fajsz határa. In J. Kisfaludi (ed.), Régészeti Kutatások Magyarországon 2001. Archaeological Investigations in Hungary 2001. Budapest: 162.

Bánffy E., Marton T. and Osztás A. 2010. Early neolithic settlement and burials at Alsónyék-Bátaszék. In J. K. Kozłowski, P. Raczky (eds.), Neolithisation of the Carpathian Basin: Northernmost distribution of the Starcevo/Körös culture. Papers presented on the symposium organized by The EU Project FEPRE (The Formation of Europe: Prehistoric Population Dynamics and the Roots of Socio-Cultural Diversity), Kraków-Budapest: 37-51.

Bertók G., Gáti Cs. 2011. Neue Angaben zur spätneolithischen Siedlungsstruktur in Südosttransdanubien. Acta Archaeologica Academiae Scientiarum Hungaricae 62: $1-28$.

Bittner B. 2012a. Catalogue of Körös culture sites in JászNagykun-Szolnok county. In A. Anders, Zs. Siklósi (eds.), 
The First Neolithic Sites in Central/South-East European Transect. Volume III: The Körös Culture in Eastern Hungary. BAR IS 2334. Archaeopress, Oxford: 235-252.

2012b. Catalogue of Körös culture sites in Békés county. In A. Anders, Zs. Siklósi (eds.), The First Neolithic Sites in Central/South-East European Transect. Volume III: The Körös Culture in Eastern Hungary. BAR IS 2334. Archaeopress, Oxford: 257-296.

Bondár M. 1995. The settlement of the Lengyel culture at Zalaszentbalázs. Antaeus 22: 51-70.

von Brandt D. 1980. Die linearbandkeramischen Häuser des Siedlungsplatzes Langweiler 8. Unpublished $\mathrm{PhD}$ thesis. Fakultät für Bauwesen der Rheinisch-Westfälischen Technischen Hochschule Aachen. Aachen.

Carneiro Â. 2006. Die eingetiefte Siedlungskonstruktion von Mannersdorf an der March in Niederösterreich und die eingetieften Bauten der Lengyelkultur. In A. KrennLeeb, K. Grömer und P. Stadler (eds.), Ein Lächeln für die Jungsteinzeit. Ausgewählte Beiträge zum Neolithikum Ostösterreichs. Festschrift für Elisabeth Ruttkay. Archäologie Österreichs 17/2: 70-81.

Dani J. 2012. Catalogue of Körös culture sites in HajdúBihar county. In A. Anders, Zs. Siklósi (eds.), The First Neolithic Sites in Central/South-East European Transect. Volume III: The Körös Culture in Eastern Hungary. BAR IS 2334. Archaeopress, Oxford: 253-255.

Dobeš M., Fojtík P., Kalábek M., Kalábková P. and Peška J. 2010. K počátkům výskytu měděné industrie na Moravě, sekery z Hulína-Pravčic a Laškova-Kandie. Of the beginning of appearance of copper tools in Moravia, axes from Hulín-Pravčice and Laškov-Kandia. Přehled výzkumů 51: 57-68.

Dombay J. 1939. A zengôvárkonyi ôskori telep és temetô. The prehistoric settlement and cemetery at Zengôvárkony. Archaeologia Hungarica 23.

1958 (1959). Kôrézkori és kora vas-kori település nyomai a pécsváradi Aranyhegyen. Überreste einer aeneolithischen und früheisenzeitlichen Ansiedlung an Berg Arany (Goldberg) bei Pécsvárad. Janus Pannonius Múzeum Évkönyve 3: 53-102.

1959 (1960). Próbaásatás a villánykövesdi kôrézkori lakótelepen. Probegrabung an der aeneolithischen Ansiedlung bei Villánykövesd (Kom. Baranya). Janus Pannonius Múzeum Évkönyve 4: 55-73.

1960. Die Siedlung und das Gräberfeld in Zengóvárkony: Beiträge zur Kultur des Aeneolithikums in Ungarn. Archaeologia Hungarica, dissertationes Archaeo- logicae Musei nationalis Hungarici. Series nova. 37. Akadémiai kiadó. Budapest.

M. Egry I. 2001. Beszámoló a Győr-Marcalváros-Bevásárlóközpont területén végzett megelőző régészeti feltárásokról. Report on the Preliminary Exploration Carried out on the Area of Gyôr-Marcalváros-Shopping Centre. Arrabona 39/1-2: 57-78.

2003. Rézkori településrészlet Mosonszentmiklós-Egyéni földek lelőhelyen. Das Detail einer kupferzeitlichen Siedlung auf dem Fundort Mosonszentmiklós-Egyéni földek. Móra Ferenc Múzeum Évkönyve - Studia Archaeologica IX: 95-100.

Figler A. 1993. Gyôr-Szabadrétdomb. Régészeti Füzetek 45: $14-15$.

1997. Mosonszentmiklós-Pálmajor. Régészeti Füzetek 48: $19-20$.

Gallina Zs., Hornok P., Paluch T. and Somogyi K. 2010. Elôzetes jelentés az M6 AP T0 10/B és 11. számú lelôhelyrészen végzett megelőző feltárásról. Alsónyék-Bátaszék (Tolna megye) 2006-2009. Vorbericht über die präventive Ausgrabung am Fundortsteil Nr. M6 AP TO 10/B und 11. Alsónyék-Bátaszék (Komitat Tolna) 2006-2009. Wosinsky Mór Múzeum Évkönyve 32: 7-100.

Gelencsér Á. 2010. Alsónyék/Bátaszék-Malomréti-dúlő (Tolna megye, To 11. lelőhely). In. J. Kvassay (ed.), Évkönyv és jelentés a Kulturális Örökségvédelmi Szakszolgálat 2008. évi feltárásairól. Field Service for Cultural Heritage 2008. Yearbook and review of archaeological investigations. Kulturális Örökségvédelmi Szakszolgálat. Field Service for Cultural Heritage, Budapest: 16-17.

Horváth L., Kalicz N. 2003. Újkőkori település feltárása Petriventén (Zala megye). Excavation of a Neolithic site at Petrivente (Zala county). In. J. Kisfaludi (ed.), Régészeti Kutatások Magyarországon 2001. Archaeological Investigations in Hungary 2001, Budapest: 5-29.

Ilon G., Farkas Cs. 2001. Houses of the late-Lengyeli Settlement at the boundary of Szombathely (county Vas, Western Hungary). In J. Regenye (ed.), Sites and Stones: Lengyel Culture in Western Hungary and Beyond. A Review of the Current Research. Directorate of the Veszprém County Museums, Veszprém: 55-60.

Kalábek M., Kalábková P. and Peška J. 2009. Hulín (okr. Kroměřǐž) 'Višňovce'. LnK. Sídliště. Záchranný výzkum. Přehled výzkumu 50: 248-249.

Kalicz N. 1985. Kókori falu Aszódon. Neolithisches Dorf in Aszód. Múzeumi Füzetek 32. 
1994. A dunántúli (közép-európai) vonaldíszes kerámia legidősebb leletei és a korai Vinča kultúra (Die ältesten Funde der transdanubischen (mitteleuropäischen) Linienbandkeramik und die frühe Vinča-Kultur). In G. Lőrinczy (ed.), A kókortól a középkorig. Tanulmányok Trogmayer Ottó 60. születésnapjára. Von der Steinzeit bis zum Mittelalter. Studien zum 60. Geburtstag von Ottó Trogmayer. Csongrád Megyei Múzeumok Igazgatósága, Szeged: 67-84.

2003. Az újkőkorvégi és rézkori megtelepedés maradványai a nagykanizsai Inkey-kápolna mellett (Kr.e. 5. évezred első harmadától a 3. évezred első feléig). Endneolithische und kupferzeitliche Besiedlung bei Nagykanizsa (Inkey-Kapelle). Zalai Múzeum 12: 7-47.

2008. Aszód: ein gemischter Fundort der Lengyel- und Theiss-Kultur. Communicationes Archaeologicae Hungariae 2008: 5-54.

2011. Forschung über die Starčevo-Kultur in Südtransdanubien (Ungarn). In K. Botić, S. Kovačević, D. L. Dizdar (eds.), Panonski prapovijesni osviti. Zbornik radova posvećenih Korneliji Minichreiter uz 65. obljetnicu života. Institut za arheologiju, Zagreb: 105-129.

Kalicz N., Makkay J. 1972. A neolitikus Sopot-Bicske kultúra. Die neolithische Sopot-Bicske-Kultur. Archaeologiai Értesító 99: 3-13.

Kalicz N., Molnár S. and Rózsás M. 2007a. Az élelemtermelés kezdetei Somogy megyében a Kr.e. 7-6. évezred fordulóján. Az újkőkor (neolitikum) legidôsebb szakasza. Beginnings of food production in Somogy county at the turn of the $7^{\text {th }}-6^{\text {th }}$ millenia B.C. The earliest phase of the Neolithic Period. Communicationes Archaeologicae Hungariae 2007: 19-64.

Kalicz N., Kreiter E. and Tokai Z.M. 2007b. Die Rolle der Sopot-Kultur in der Entstehung der Lengyel-Kultur auf Grund der Neuen Ausgrabungen in Südwestungarn. In J. K. Kozłowski, P. Raczky (eds.), The Lengyel, Polgár and related cultures in the Middle/Late Neolithic in Central Europe. Jagiellonian University and ELTE, Kraków: 29-47.

Károlyi M. 1982. Kisunyom-Nádasi tábla. Archaeologiai Értesító 109: 295-296.

1992. A korai rézkor emlékei Vas megyében. The Early Copper age in county Vas. Óskorunk 1. Vas Megyei Múzeumok Igazgatósága. Szombathely.

Kustár R. 2012. Catalogue of Körös culture sites in BácsKiskun county. In A. Anders, Zs. Siklósi (eds.), The First Neolithic Sites in Central/South-East European Transect. Volume III: The Körös Culture in Eastern Hungary. BAR IS 2334. Archaeopress, Oxford: 323-329.
Lichter C. 1993. Untersuchungen zu den Bauten des südosteuropäischen Neolithikums und Chalkolithikums. Internationale Archäologie 18. Verlag Marie Leidorf. Buch am Erlbach.

Majerik V., Nicklas L. and Gelencsér Á. 2010. BátaszékKanizsai-dúlő/Lajvér (Tolna megye, TO 46. lelőhely. In. J. Kvassay (ed.), Évkönyv és jelentés a Kulturális Örökségvédelmi Szakszolgálat 2008. évi feltárásairól. Field Service for Cultural Heritage 2008. Yearbook and review of archaeological investigations. Kulturális Örökségvédelmi Szakszolgálat. Field Service for Cultural Heritage, Budapest: $17-18$.

Marton T., Oross K. 2012. Siedlungsforschung in linearbandkeramischen Fundorten in Zentral- und Südtransdanubien - Wiege, Peripherie oder Beides? In R. Smolnik (ed.), Siedlungsstruktur und Kulturwandel in der Bandkeramik. Beiträge der internationalen Tagung. 'Neue Fragen zur Bandkeramik oder alles beim Alten?! Leipzig, 23. bis 24. September 2010. Arbeits- und Forschungsberichte zur sächsischen Bodendenkmalpflege, Beiheft 2. Landesamt für Archäologie. Dresden: 220-240.

Masuch A., Ziessow K.-H. 1985. Reconstructing Linear Culture Houses: Theoretical and Practical Contributions. Helinium 25: 58-93.

Minichreiter K. 2007. Slavonski Brod Galovo. Deset godina arheoloških istraživanja. Ten years of archaelogical excavations. MIA 1, Institut za Arheologiju. Zagreb.

Minichreiter K., Botić K. 2010. Early Neolithic burials of Starčevo culture at Galovo, Slavonski Brod (Northern Croatia). In M. Budja (ed.), 17th Neolithic Studies. Documenta Praehistorica 37: 105-124.

Müller-Karpe H. 1968. Handbuch der Vorgeschichte. Band II. Jungsteinzeit. C. H. Beck. München.

T. Németh G. 1994. Vorbericht über spätneolithische und rühkupferzeitliche Siedlungsspuren bei Lébény (Westungarn). Jósa András Múzeum Évkönyve 36: 241-261.

Oross K. 2008. Sag mir, wo die Pfosten sind, wo sind sie geblieben? Bemerkungen zur Frage der linearbandkeramischen Hausgrundrisse mit drei Pfostenreihen in Ungarn. Ósrégészeti Levelek - Prehistoric Newsletter 10: 77-88.

Oross K., Bánffy E. 2009. Three successive waves of Neolithisation: LBK development in Transdanubia. In M. Budja (ed.), $16^{\text {th }}$ Neolithic Studies. Documenta Praehistorica 36: 175-189.

Paluch T. 2012. Catalogue of Körös culture sites in Csongrád county. In A. Anders, Zs. Siklósi (eds.), The First Neolithic Sites in Central/South-East European Transect. 
Volume III: The Körös Culture in Eastern Hungary. BAR IS 2334. Archaeopress, Oxford: 297-322.

Patay P. 1985. Über die Bauten des Neolithikums und der Kupferzeit im Karpatenbecken. In M. Liverani, A. Palmieri and R. Peroni (eds.), Studi di Paletnologia in onore di Salvatore M. Puglisi. Dipartimento di scienze storiche, archeologiche e antropologiche dell'antichità in Roma. Università di Roma 'La Spaienza', Roma: 547- 553.

Pavúk J. 1991. Lengyel-culture fortified settlements in Slovakia. Antiquity 65: 348-357.

2003. Hausgrundrisse der Lengyel-Kultur in der Slowakei. In J. Eckert, U. Eisenhauer and A. Zimmermann (eds.), Archaologische Perspektiven. Analysen und interpretationen im Wandel. Festschrift für Jens Lüning zum 65. Geburtstag. Internationale Archäologie. Studia honoraria 20. Vlg Marie Leidorf, Rahden: 455469.

Pusztai R. 1956. A szemelyi kôrézkori ház. Das aeneolithische Haus von Szemely. Archaeologiai Értesító 83: 39-44.

Raczky P. 1974. A lengyeli kultúra legkésóbbi szakaszának leletei a Dunántúlon. Funde der spätesten Phase der Lengyel-Kultur in Westungarn. Archaeologiai Értesító 101: 185-210.

2005. Újkőkori ház kísérleti rekonstrukciója PolgárCsőszhalom településéról. Experimental reconstruction of a Neolithic house at the Polgár-Csôszhalom settlement. Ósrégészeti Levelek - Prehistoric Newsletter 7: 24-49.

2006. House-structures under change on the Great Hungarian Plain in earlier phases of the Neolithic. In N. Tasić, C. Grozdanov (eds.), Homage to Milutin Garašanin. Serbian Academy of Sciences and Arts, Belgrade: 379-398.

Raczky P., Anders A. 2006. Social dimensions of the Late Neolithic settlement of Polgár-Csószhalom (Eastern Hungary). Acta Archaeologica Academiae Scientiarum Hungaricae 57: 17-33.

Regenye J. 2000. A lengyeli kultúra újabb lelóhelyei Veszprém megyében. Veszprém Megyei Múzeumok Közleményei 21: 9-19.

2001. Lengyel culture settlements around Tűzköveshegy in Szentgál (Veszprém county, Hungary). In J. Regenye (ed.), Sites and Stones: Lengyel Culture in Western Hungary and Beyond. A Review of the Current Research. Directorate of the Veszprém County Museums, Veszprém: 71-79.
2002. Chronological situation of the Sopot culture in Hungary. Veszprém Megyei Múzeumok Közleményei 22: 31-42.

2004. Háztípusok és településszerkezet a késői lengyeli kultúrában veszprémi és szentgáli példák alapján. House types and settlement structure in the Late Lengyel culture, based in the examples at Veszprém and Szentgál. Veszprém Megyei Múzeumok Közleményei 23: 25-47.

2007. The Late Lengyel culture in Hungary as reflected by the excavation at Veszprém. In J. K. Kozłowski, P. Raczky, P. (eds.), The Lengyel, Polgár and related cultures in the Middle/Late Neolithic in Central Europe. Jagiellonian University and ELTE, Kraków: 381-396.

2011. Kó és agyag. Település és életmód a neolitikumrézkor fordulóján a Dunántúlon. Stone and clay. Settlement and way of life at the Neolithic/Copper age transition in Transdanubia. Veszprém Megyei Múzeumi Igazgatóság vezetôje. Veszprém.

Siklósi Zs. 2010. A társadalmi egyenlótlenség nyomai a késó neolitikumban a Kárpát-medence keleti felén. (Traces of social inequality during the Late Neolithic in the Eastern Carpathian Basin). Unpublished PhD thesis. Eötvös Loránd University, Budapest.

2012. Catalogue of Körös culture sites in Szabolcs-Szatmár-Bereg county. In A. Anders, Zs. Siklósi (eds.), The First Neolithic Sites in Central/South-East European Transect. Volume III: The Körös Culture in Eastern Hungary. BAR IS 2334. Archaeopress, Oxford: 235.

H. Simon K. 1987. Neolit és rézkori települések Tekenye határában. Zalai Múzeum 1: 7-46.

M. Virág Z. 2004. Településtörténeti és kronológiai kutatások a Dunántúlon és Budapest környékén a középsó rézkor elsó felében. (Settlement historical and chronological investigations in Transdanubia and in the environs of Budapest in the first half of the Middle Copper Age). Unpublished PhD thesis. Eötvös Loránd University. Budapest.

2005. Középsô rézkori épületek rekonstrukciós lehetôségeirốl. Reconstruction of a Middle Copper Age house. Ósrégészeti Levelek - Prehistoric Newsletter 7: 60-72.

M. Virág Z., Figler A. 2007. Data on the settlement history of the Late Lengyel period of Transdanubia on the basis of two sites from the Kisalföld (Small Hungarian Plain). A preliminary evaluation of the sites Gyôr-Szabadrétdomb and Mosonszentmiklós-Pálmajor. In J. K. Kozłowski, P. Raczky, P. (eds.), The Lengyel, Polgár and related cultures in the Middle/Late Neolithic in Central Europe. Jagiellonian University and ELTE, Kraków: 345-364. 
Zalai-Gaál I. 1990. A neolitikus körárokrendszerek kutatása a Dél-Dunántúlon (Die Erforschung der neolithischen Kreisgrabensysteme in SO-Transdanubien). Archaeologiai Értesító 117: 3-24.

2001. A késôi neolitikum története a Dél-Dunántúlon a temetốlemzések tükrében (tipológia - kronológia - társadalomrégészet). Akadémiai doktori értekezés. Budapest.

2008. An der Wende vom Neolithikum zur Kupferzeit in Transdanubien (Ungarn): Die 'Häuptlingsgräber' der Lengyel-Kultur in Alsónyék-Kanizsa. Altertum 53(4): 241-280.

2010. Die soziale Differenzierung im Spätneolithikum Südtransdanubiens. Die Funde und Befunde aus den alten Ausgrabungen. Varia Archaeologica Hungarica 24. Archaeolingua. Magyar Tudományos Akadémia Régészeti Intézete. Budapest.

Zalai-Gaál I., Osztás A. 2009a. A lengyeli kultúra települése és temetôje Alsónyék-Kanizsa-dúlóben. In L. Bende, G. Lốrinczy (eds.), Medinától Etéig. Régészeti Tanulmányok Csalog József születésének 100. évfordulójára. Szentes: $245-254$.

2009b. Neue Aspekte zur Erforschung des Neolithikums in Ungarn. Ein Fragenkatalog zu Siedlung und Gräberfeld der Lengyel-Kultur von Alsónyék, Südtransdanubien. In V. Becker, M. Thomas and A. Wolf-Schuler (eds.), Zeiten-Kulturen-Systeme. Gedenkschrift für Jan Lichardus. Schriften des Zentrums für Archäologie und Kulturgeschichte des Schwarzmeerraumes 17. Zentrum für Archäologie und Kulturgeschichte des Schwarzmeerraumes, Langenweißbach: 111-139.
Zalai-Gaál I., Gál E., Köhler K. and Osztás A. 2009. Eberhauerschmuck und Schweinekiefer-Beigaben in den neolithischen und kupferzeitlichen Bestattungssitten des Karpatenbeckens. Acta Archaeologica Academiae Scientiarum Hungaricae 60: 303-355.

2011a. 'Ins Jenseits begleitend': Hundemitbestattungen der Lengyel-Kultur von Alsónyék-Bátaszék. Acta Archaeologica Academiae Scientiarum Hungaricae 62: 29-74.

2011b. Das Steingerätedepot aus dem Häuptlingsgrab 3060 der Lengyel-Kultur von Alsónyék, Südtransdanubien. In H.-J. Beier, R. Einicke and E. Biermann (eds.), Dechsel, Axt, Beil \& Co - Werkzeug, Waffe, Kultgegenstand? Aktuelles aus der Neolithforschung. Beiträge der Tagung der Arbeitsgemeinschaft Werkzeuge und Waffen im Archäologischen Zentrum Hitzacker 2010 und Aktuelles. Beiträge zur Ur- und Frühgeschichte Mitteleuropas 63. Varia Neolithica VII, Langenweissbach: 65-83.

Zalai-Gaál I., Köhler K. and Osztás A. 2012. Totenbrett oder Totenhütte? Zur Struktur der Gräber der Lengyel-Kultur mit Pfostenstellung in Südtransdanubien. Acta Archaeologica Academiae Scientiarum Hungaricae 63: 69-116.

2010. Zur Typologie und Stellung von Kulttischchen der Lengyel-Kultur im mittel- und südosteuropäischen Neolithikum. Acta Archaeologica Academiae Scientiarum Hungaricae 61: 305-380.

Wosinsky M. 1885. Leletek a lengyeli óskori telepról. Franklin társulat nyomdája. Budapest.

1896. Tolnavármegye az öskortól a honfoglalásig. Budapest. 